\title{
Soil improvement and mitigation of greenhouse gas emissions for integrated crop-livestock systems: Case study assessment in the Pantanal savanna highland, Brazil
}

\author{
Luz Selene Buller a,* Ivan Bergier ${ }^{\mathrm{b}}$, Enrique Ortega a , Anibal Moraes ${ }^{\mathrm{c}}$, \\ Gustavo Bayma-Silva ${ }^{\mathrm{d}}$, Marilia Ribeiro Zanetti ${ }^{\mathrm{d}}$ \\ a Ecological Engineering Laboratory, Food Engineering School, State University of Campinas, Rua Doutor Josué de Castro 40, Cidade Universitária, Campinas, \\ SP, CEP 13083-862, Brazil \\ ${ }^{\mathrm{b}}$ Biomass Conversion Laboratory, Embrapa Pantanal, Brazilian Agricultural Research Corporation, Rua 21 de Setembro 1880, Bairro Nossa Senhora de \\ Fátima, Corumbá, MS, CEP 79320-900, Brazil \\ ' Department of Agricultural Sciences, Federal University of Paraná, Rua dos Funcionários 1540, Cabral, Curitiba, PR, CEP 80035-050, Brazil \\ d Embrapa Satellite Monitoring, Brazilian Agricultural Research Corporation, Avenida Soldado Passarinho 303, Fazenda Chapadão, Campinas, SP, CEP \\ 13070-115, Brazil
}

\section{A R T I C L E I N F O}

\section{Article history:}

Received 2 July 2014

Received in revised form 15 November 2014

Accepted 20 November 2014

Available online 17 December 2014

\section{Keywords:}

Emergy synthesis

Renewable energy

Nutrient cycling

Ecohydrology

GHG mitigation

\begin{abstract}
A B S T R A C T
Greenhouse gas emissions and climate change has been partially attributed to agricultural expansion by deforestation, while the pressure to assure food, fiber and energy for the future generations leads to the intensification of agricultural systems. The transition to more efficient systems is actually considered an important strategy to reduce deforestation and to spare land for other uses, including the recovery of environmental services and ecohydrological processes in the drainage basin such as carbon sink and water regulation. The Brazilian Federal Program for Low Carbon Agriculture (ABC Program) intends to reduce carbon emissions by stimulating technological processes that neutralize emissions or enhance the sinking of greenhouse gases. A pilot farm has been established to assess an intensive animal-plant farming system that incorporates anaerobic digestion for biogas, power generation and organic fertilizer production. Emergy Synthesis was chosen as a methodological tool to assess and to diagnosis the farm system design. The modified emergy assessment including externalities (greenhouse gas emissions) improves the understanding of integrated crop-livestock systems efficiency in internal recycling of nutrients and power conversion. The adoption of manure treatment in intensified agricultural systems can effectively contribute to enhance environmental and economic performances.
\end{abstract}

(c) 2014 Elsevier Ltd. All rights reserved.

\section{Introduction}

Recent FAO estimates indicate that $12.5 \%$ of the global population is undernourished and emphasize that agricultural production and productivity growth remain essential for better nutrition (FAO, 2013). Land-use for livestock accounts for $75 \%$ of the global agricultural space that includes grain and pasture for animal feed. Despite land allocation to agriculture, there is great inefficiency in the net energy of agricultural systems since $36 \%$ of the calories produced by the world's crops are used for animal feed and only $12 \%$ of feed calories are directed to human consumption as meat and other animal products (Cassidy et al., 2013). The transition to more efficient systems is actually considered an important strategy to reduce deforestation and to spare land for other uses, including the

\footnotetext{
* Corresponding author. Tel.: +55 (19) 3521-4058; fax: +55 (19) 3521-4027.

E-mail address: selene@fea.unicamp.br (L.S. Buller).
}

recovery of environmental services and ecohydrological processes in the drainage basin (Zalewski, 2002) such as carbon sink and water regulation (Watanabe and Ortega, 2014).

The challenge to improve the production of food, fiber and energy for the next decades is attached to the mandatory target establishing systems with low environmental externalities and resilient to climate changes (Godfray et al., 2010; Rockstrom et al., 2009). Agriculture, land-use and forestry sectors are responsible for almost a third of the total greenhouse gas (GHG) emissions, which are mainly due to enteric fermentation followed by manure left on pasture (Tubiello et al., 2014). Indeed, the agricultural sector presents a substantial potential for climate change mitigation by improvements in the efficiency of agricultural production (Bennetzen et al., 2012; Mueller et al., 2012).

In the last decades, Brazil has consolidated its position as an important player in agricultural commodities, in particular by agriculture expansion into the Brazilian savanna (Cerrado biome) (Rada, 2013). In spite of the retraction of the deforestation rate since 
the mid-2000s in Brazil (Lapola et al., 2014), the conversion of Cerrado natural areas into pasture has reached about $60 \%$ of its original area in the plateau of the eastern Pantanal (Silva et al., 2011). More recently, in the last two decades, conversion of pasture to largescale mono-crops (soybean, corn) in flat land areas has occurred (Lapola et al., 2014). Besides to the intense deforestation, Cerrado's soil is characterized as deficient in important nutrients (much oxidized, high iron and aluminum contents) and prone to weathering and degradation (Chapin et al., 2012). In general, areas degraded by cattle trampling in the Brazilian Cerrado have lost soil carbon (Wantzen et al., 2012) due to incorrect pasture management and the lack of renewal of exported nutrients by the cattle industry.

The Cerrado biome covers three aquifers (Guarani, Bambuí and Urucuia) responsible for feeding the greatest rivers of the South American continent. The replacement of native vegetation (characterized by deep roots) for temporary vegetation (with subsurface roots) can cause excessive runoff compromising the recharge of the aquifers (Barbosa, 2011) and other ecohydrological disruptions as those reported to the Pantanal (Bergier, 2013). Sustainable crop management associated with restoration and conservation of native vegetation in riparian zones and the adoption of agricultural "Best Management Practices" such as terraces and sediment retention basins can effectively contribute to a sustainable water resources management in Cerrado (Strauch et al., 2013). A sustainable agricultural intensification can be achieved with the use of technologies for reducing negative externalities, promoting improved yields, while controlling GHG emissions, and conserving biodiversity and ecohydrological processes (Godfray et al., 2010; Mueller et al., 2012).

In Brazil, soil carbon stocks were reduced in $\sim 6$ billion metric tons in the early 2000s and land-use change is still the major source of GHG emission, accounting for almost two-thirds of the annual global emissions (World Bank, 2010). Beyond land-use change, agriculture also generates direct GHG emissions mainly from chemical fertilizers, nitrogen $(\mathrm{N})$ mineralization in the soil, use of farm machinery powered by fossil fuels and cattle enteric emissions (World Bank, 2010). On the other hand, the expansion of the agricultural frontier in the Cerrado, a result of government policies that promoted an intensive agricultural model focused on commodities for export (Wood et al., 2000), faces international pressures to reduce both deforestation rate and GHG emissions (Lapola et al., 2014). Deforestation and land-use change can be constraints to the Brazilian agricultural expansion (Strassburg et al., 2014). Intensified and integrated agricultural systems that include arboreal element in the agroecosystem, such as the systems evaluated in the present study, can perform an important role to the mitigation of deforestation and GHG emissions (Burney et al., 2010), as well as to restore vital ecohydrological process within the drainage basin (Barbosa, 2011; Bergier, 2013; Watanabe and Ortega, 2014).

Notwithstanding, Brazil could play a large role in the global food, fiber and energy production through the Federal Program for Low Carbon Agriculture (ABC Program) set up in 2010 after the 2009 UNFCCC meeting in Copenhagen. The ABC Program (MAPA, 2012) is a strategy focused on fostering agricultural development while reducing deforestation rate and GHG emissions. In order to be successful, the adopted technologies are focused on restoration of degraded pastures, integrated crop-livestock systems (ICLS), no-tillage, nitrogen fixation, restoration of forests and treatment of animal waste. Although the reduction of deforestation rates retains the greatest potential for mitigating GHG emissions, a low-carbon agriculture can also reduce GHG emissions, facilitate the removal of carbon, increase livestock productivity, and reestablish large areas of grassland currently used inefficiently in the Cerrado (Austin et al., 2013). In addition to helping mitigate GHG emissions, the treatment of animal waste co-products can support clean power production and leverage a Clean Development Mechanism generating socioeconomic gains to producers, and contributing to avoid surface and groundwater pollution. Soil and water contamination can occur through incorrect applications of manure, i.e., without manure treatment to reduce micro and macronutrients loadings, which can seep into deeper layers of soil and reach the groundwater (Kunz et al., 2009).

Brazilian agriculture could become a carbon sink (World Bank, 2010) by means of technological improvements for intensification and management practices that actually are solutions to reduce environmental externalities, to avoid soil erosion and to build up soil carbon while increasing productivity (Lapola et al., 2014). The effects of increasing productivity per unit of agricultural output could be ambiguous on GHG emissions mitigation if investments are focused solely on input intensification (Valin et al., 2013). Agricultural yield improvements are highly dependent on $\mathrm{N}$ supply, one of the main limiting factors in tropical and subtropical soils. Most of the inputs of reactive nitrogen in terrestrial agroecosystems are based on synthetic fertilizers (Haber-Bosch synthesis) because, although the atmosphere is rich in reactive nitrogen, only a limited number of microorganism species have the ability to convert it by biological fixation (Austin et al., 2013). Nitrogen addition can eventually increase carbon sequestration by soils, but it also stimulates the release of nitrous oxide $\left(\mathrm{N}_{2} \mathrm{O}\right)$, a GHG with global warming potential 300 times greater than carbon dioxide $\left(\mathrm{CO}_{2}\right)$ in the time horizon of 100 years (Zaehle et al., 2011).

Although till farming system is the conventional practice worldwide, no-till system, which is recommended by the ABC Program, can be an efficient management that reduces $\mathrm{N}_{2} \mathrm{O}$ emissions from soil and promotes soil $\mathrm{C}-\mathrm{CO}_{2}$ sequestration, contributing to a low carbon and low GHG emission agriculture (Piva et al., 2012). Additionally, a long-term no-till system (more than 20 years) strongly improves soil mechanical characteristics, hydrological properties and carbon concentration (Kahlon et al., 2013). Nevertheless, the improvement might be valid particularly for warm and dry regions (Pittelkow et al., 2014), along with integrated nutrient management practices (Lal, 2004, 2013). Hence, more research is necessary to balance till and no-till benefits (Godfray et al., 2010).

Carvalho et al. (2014) recently observed that the adoption of croplivestock rotation systems is an efficient strategy to sink soil carbon and to mitigate soil GHG emissions in the Brazilian Cerrado. Integrated crop-livestock systems characterized by rotation of pastures and crops in different timescales in a no-till system are intensification strategies with sustainability that can provide environmental benefits, less vulnerability, higher yields and more financial gains when compared with monocultures or non-integrated livestock farming (Lemaire et al., 2014; Moraes et al., 2014).

This paper uses the Emergy Synthesis to assess the sustainability of an ICLS system in the Brazilian Cerrado, precisely in the headwaters of important rivers of the Pantanal wetland. The agroecosystem was established by the Brazilian government, in the context of the ABC Program, aiming to assess an ICLS equipped with treatment of animal waste (anaerobic biodigester) that allows the reduction of GHG emissions, energy generation, and the production and recycling of organic fertilizer as an alternative to minimize the use of synthetic fertilizers.

\section{Material and methods}

\subsection{Background}

The Brazilian Agricultural Research Corporation (EMBRAPA) has a key role in the development of new farming systems in Brazil. EMBRAPA together with the Ministry of Science, Technology and Innovation (MCTI), the Ministry of Agriculture, Livestock and Food Supply (MAPA) and several Brazilian universities, has established the pilot farm in the CerradoPantanal ecotone that integrates swine, crop, pasture and eucalyptus. The system is based on cultivated pasture in rotation with biennial crops while swine is a non-stopping system (Bergier et al., 2012, 2013a).

The main agricultural activities in the region are cattle and grain crops. Cattle ranching is by far the main land-use in the region followed by soybean monocrops (Lapola et al., 2014). However, this intensive swine 
a)

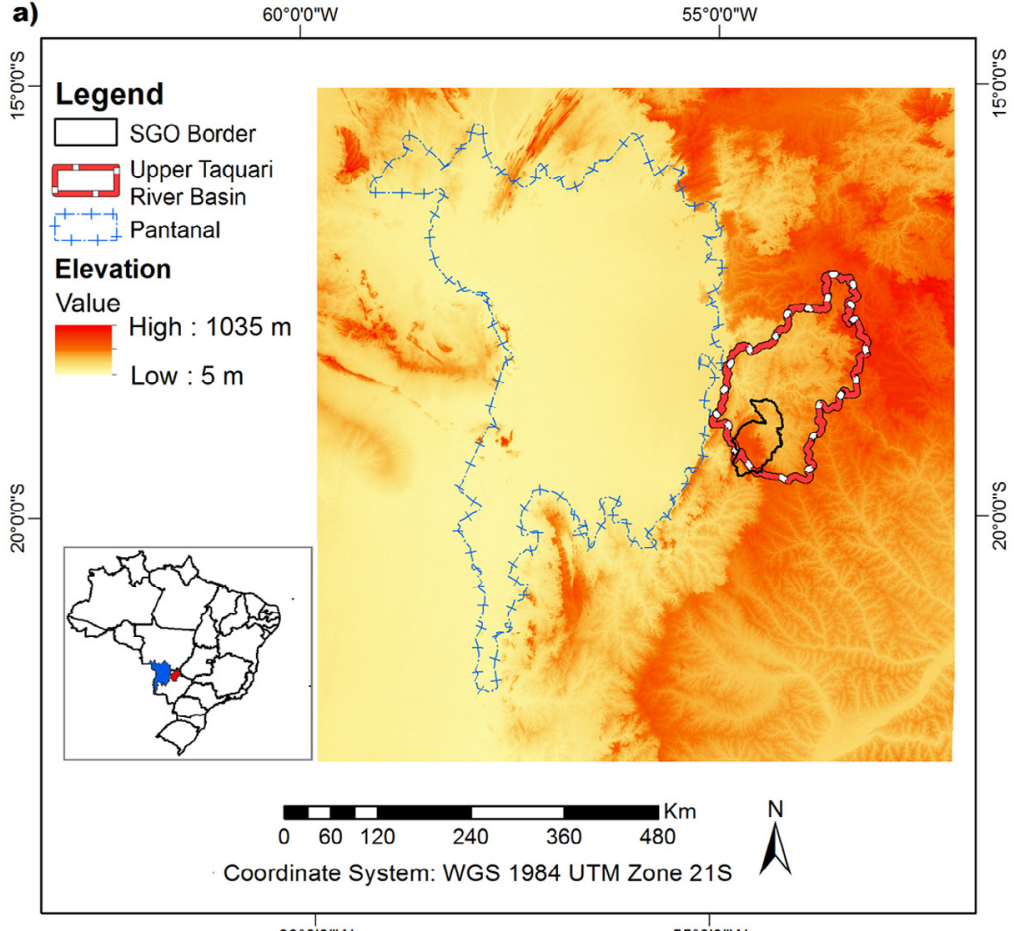

b)

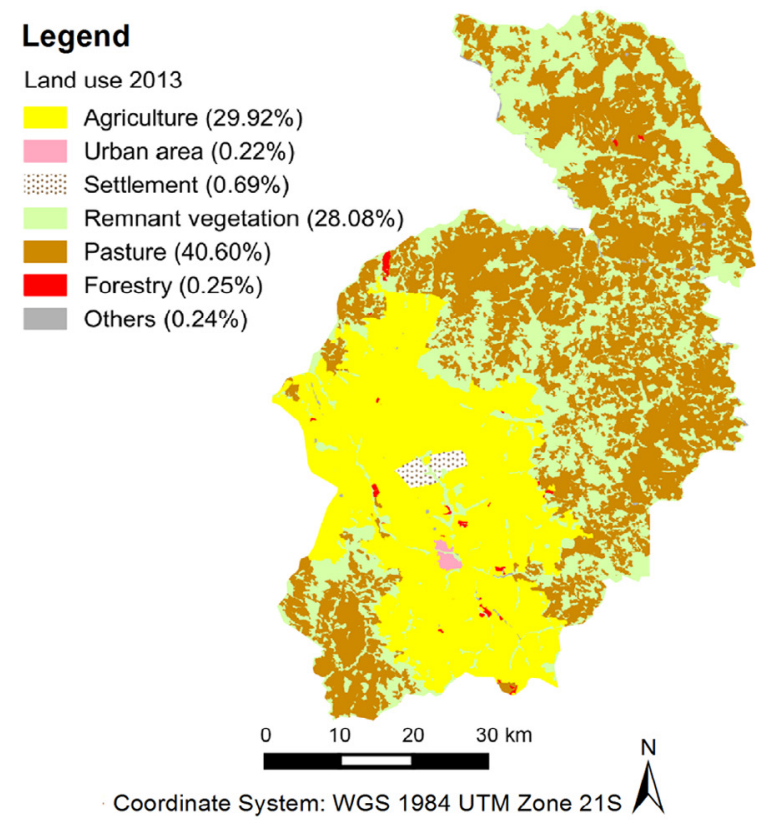

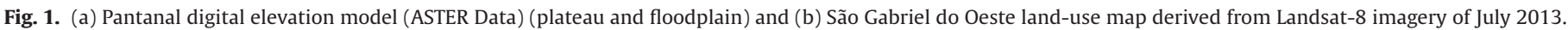
Remote sensing data source (USGS 2014, Earth Explorer).

industry has been gaining large economic importance in the last decades, and swine manure's potential risk of water and soil contamination must be considered. Nutrient recycling and manure management are the best solutions and create opportunities to obtain gains in ecosystem services and GHG reduction (Bergier et al., 2012, 2013a). The proposed farming system is an alternative to intensified and integrated agricultural system including swine. In this study, it is entitled integrated swinecrop-pasture-eucalyptus system (ISCPE). The results obtained in this research are expected to guide regional development meetings and to contribute to the Brazilian ABC Program scope.

\subsection{Experimental site description}

The pilot farm is located in São Gabriel do Oeste, Mato Grosso do Sul, Brazil (Campanário Settlement - 19¹6'46.90"S, 54³6'2.35”W) maintained by a local agricultural cooperative (Fig. 1). The Upper Taquari River Basin (highlands) encloses the region under study, which is an important tributary of the Paraguay River in the Upper Paraguay Basin. The Pantanal wetland in the lowlands is affected by pasture and agricultural activities in the highlands and the ongoing land-use changes in the highlands has already caused deleterious effects on the Pantanal ecohydrology (Bergier, 2013).

Remaining native vegetation cover in São Gabriel do Oeste in 2013 is $28 \%$, reflecting the agriculture expansion in the county due to flat topography. An interactive land-use map for São Gabriel do Oeste is available in GeoNode, a web-based application and platform (GeoNode, 2014).

Regarding the pilot farm organization, pigs are marketed after 120 days of confinement, i.e., three cycles of swine production per year, integrating annually 6,000 pigs on a total cropland area of 22.40 ha. The manure anaerobic biodigestion has three main outputs (Fig. 2), biogas for power generation, liquid and solid organic fertilizer, which can replace synthetic fertilizers in crop soils. The biogas has about $60 \%$ methane $\left(\mathrm{CH}_{4}\right)$ by volume, which has a heat of combustion of around $55 \mathrm{MJ}$ per $\mathrm{kg}$ of $\mathrm{CH}_{4}$. A local company named Retificadora Centro Sul has devel- oped a power generator (Rieger, 2006) to convert the biogas into either mechanical or electrical energy with $41 \%$ efficiency. Instead of simply burning $\mathrm{CH}_{4}$ to decrease its radiative impact on climate change, the project uses it in a more sustainable way (Bergier et al., 2013a). A fraction of the power is used to apply the liquid organic fertilizer onto pasture, crop, and forestland, or combinations of these in different proportions. This process is called fertigation, and a thousand swine may produce about 3,650 $\mathrm{m}^{3}$ (Bergier et al., 2013a). Retificadora Centro Sul also designed the technology for the liquid organic fertilizer

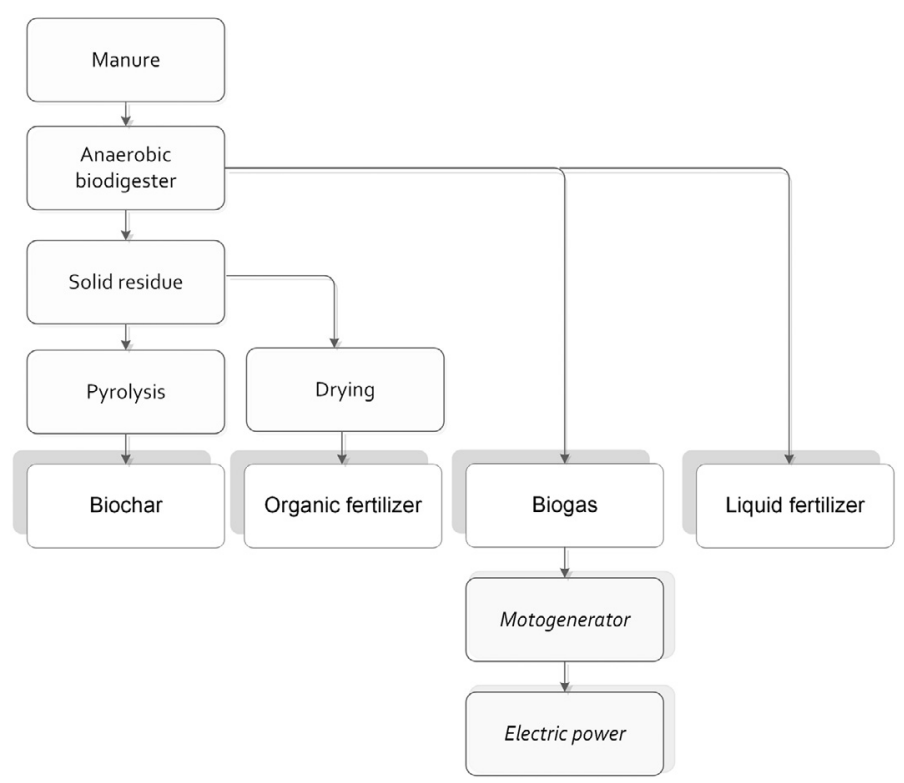

Fig. 2. Anaerobic biodigester outputs. 


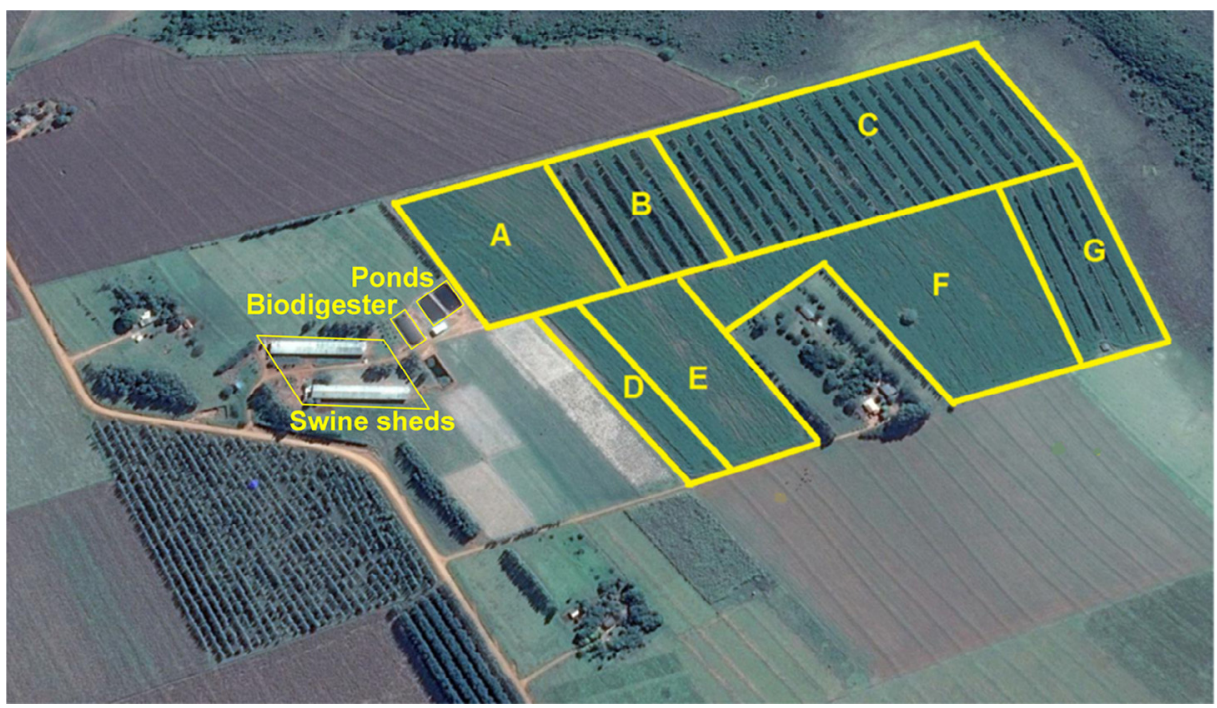

Fig. 3. Spatial distribution of the integrated systems in the pilot farm. Google Earth ${ }^{\circledR}$ image.

Table 1

Pilot farm portions and areas.

\begin{tabular}{|c|c|c|}
\hline Portion & Area (ha) & Production system \\
\hline A & 3.00 & Permanent pasture with mineral fertilizer \\
\hline B & 2.10 & Permanent wooded pasture with mineral fertilizer \\
\hline C & 7.40 & $\begin{array}{l}\text { Integrated crop-livestock-forestry with mineral fertilizer } \\
\text { and fertigation }\end{array}$ \\
\hline $\mathrm{D}$ & 1.00 & Integrated crop-livestock with fertigation \\
\hline $\mathrm{E}$ & 2.00 & $\begin{array}{l}\text { Integrated crop-livestock with mineral fertilizer and } \\
\text { fertigation }\end{array}$ \\
\hline $\mathrm{F}$ & 5.10 & Integrated crop-livestock with mineral fertilizer \\
\hline G & 1.80 & Integrated crop-livestock-forestry with mineral fertilizer \\
\hline Total & 22.40 & \\
\hline
\end{tabular}

dispersion, which includes a special irrigation design driven by biogas (Rieger, 2006).

The effluent produced by every thousand swine can sustainably fertigate about 10 ha and it has been applied to pasture, corn, soybean fields and a small eucalyptus plantation at a rate of $180 \mathrm{~m}^{3}$ of organic fertilizer per hectare per crop cycle (Bergier et al., 2012). Eucalyptus (Eucalyptus urograndis) was planted in 2011 and 2012. Since 2011 until present, field data have been collected to quantify the chemicals applied, including fertilizers, herbicides and pesticides, organic (manure) fertilizer application and productivity for all the portions of the pilot farm described in Table 1 and Fig. 3.

\subsection{Pilot farm field data}

From September 2013 to June 2014, soil gaseous emissions (Table 2) were monitored using a soil static chamber. Fluxes were usually measured in the morning. The closed soil chamber was deployed weekly in portions $A-G$ in at least four replicates. The chamber was connected by inlet and outlet tubing to a photo-acoustic gas analyzer ${ }^{1}$ adjusted with optical filters for measuring $\mathrm{CH}_{4}, \mathrm{CO}_{2}$ and $\mathrm{N}_{2} \mathrm{O}$. The deployment time was set to 10 minutes and the sampling rate to 1 minute.

From 2012 to 2014, the contents of micro ( $\mathrm{Zn}, \mathrm{Cu})$ and macronutrients $(\mathrm{P}, \mathrm{K})$ at different soil depths, 0-5 cm, 5-10 cm, 10-

\footnotetext{
1 Photo-acoustic gas analyzer model 1412 (Lumasense Inc.), calibrated with the aid of a gas chromatograph FID/ECD SRI Inc. and a Ultraportable Greenhouse Gas Analyzer LGR Inc.
}

$20 \mathrm{~cm}, 20-40 \mathrm{~cm}$, were measured in all of the pilot farm portions. Kruskal-Wallis test shows that $\mathrm{P}$ measures are significantly different over the years, $p$-value $<0.05$, whereas the other micro and macronutrients changes are not significant. Refer to Fig. 4 for P results and additional figures in Appendix: Supplementary materials for $\mathrm{Zn}, \mathrm{Cu}$ and $\mathrm{K}$ results.

\subsection{Emergy assessment}

Emergy accounting is a quantitative method for evaluating environmental assets, processes and flows (Odum, 1996). Based on the thermodynamics of open systems, the method has been successfully applied to assess the performance of human-dominated systems (Cohen et al., 2006; Dong et al., 2012; Giannetti et al., 2011; Rótolo et al., 2007; Wang et al., 2014). Agriculture is a production process that interacts with the biosphere, the atmosphere, surrounding ecosystems, mineral storages, water resources and human societies, and natural resources in human economies are usually taken for free, i.e., there is no accounting for the work done by nature to produce and store them (Ulgiati and Brown, 2001). Generally, nature's contributions and its work are not considered in other sustainability assessment methods.

Emergy assessment output is a set of indicators obtained as different ratios between renewable and non-renewable flows of the system that allows comparing the system's energy conversion efficiency (Odum, 1996) pondering that all energy transformations can be arranged in an ordered series to create an energy hierarchy (Odum, 1988). The interpretation of nature's work on the renewability capability of several ecosystems, including agroecosystems, allows inferences related to the sustainability in a large framework that considers environmental and economic assets (Odum, 1996).

By definition, emergy is the embodied energy necessary to produce a flow (Odum, 1996). Energy and materials inflows for the system under study are placed on the same basis, applying a conversion factor referred to as Unit Emergy Values (UEV). UEV account for the complex interactions of biosphere processes in a unit known as "solar equivalent Joule" (seJ), i.e., emergy accounts for direct solar radiation required in all involved processes to produce goods and services in an energy hierarch (Odum, 1996). The solar emergy required to make one unit of a product or service is named "transformity" (seJ.J-1 ) for flows measures in energy, and "specific 
Table 2

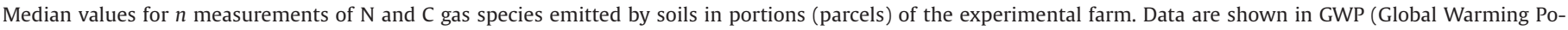
tential) in $\mathrm{CO}_{2}$ equivalents for the greenhouse gases.

\begin{tabular}{|c|c|c|c|c|c|c|c|c|}
\hline \multicolumn{2}{|c|}{ Portion } & \multirow{2}{*}{$\begin{array}{l}\mathrm{NH}_{3} \\
\left(\mathrm{~kg} \cdot \mathrm{ha}^{-1} \cdot \mathrm{year}^{-1}\right)\end{array}$} & $\mathrm{CO}_{2}$ & $\mathrm{CH}_{4}$ & $\mathrm{~N}_{2} \mathrm{O}$ & \multirow{2}{*}{$\begin{array}{l}\text { Total GWP } \\
\left(\mathrm{kg} \mathrm{CO}_{2} \text { eq } \cdot \mathrm{ha}^{-1} \cdot \text { year }^{-1}\right)\end{array}$} & $\mathrm{N}_{2} \mathrm{O}^{\mathrm{a}}$ & \multirow{2}{*}{$\frac{\mathrm{N}_{2} \mathrm{O}^{\mathrm{b}}}{-1)}$} \\
\hline & & & \multicolumn{3}{|c|}{$\left(\mathrm{kg} \mathrm{CO}_{2}\right.$ eq $\cdot \mathrm{ha}^{-1} \cdot$ year $\left.^{-1}\right)$} & & $\left(\mathrm{kg} \mathrm{CO}_{2}\right.$ eq $\cdot \mathrm{ha}^{-1} \cdot$ year $\left.^{-1}\right)$ & \\
\hline A & $n=122$ & 1.57 & 29,543 & -3.75 & 298 & 29,837 & 1,043 & 426 \\
\hline B & $n=123$ & 1.85 & 25,475 & -2.75 & 358 & 25,830 & 1,043 & 426 \\
\hline $\mathrm{C}$ & $n=381$ & 3.26 & 35,075 & -13.50 & 1675 & 36,736 & 1,600 & 653 \\
\hline $\mathrm{D}^{\mathrm{c}}$ & $n=122$ & 3.15 & 25,171 & -18.00 & 4509 & 29,662 & 3,886 & 1,582 \\
\hline E & $n=122$ & 2.97 & 27,974 & -10.30 & 524 & 28,488 & 1,302 & 530 \\
\hline $\mathrm{F}$ & $n=115$ & 2.81 & 26,148 & -6.75 & 1976 & 28,117 & 1,043 & 426 \\
\hline G & $n=120$ & 3.95 & 31,245 & -11.80 & 1290 & 32,524 & 1,043 & 426 \\
\hline
\end{tabular}

a Based on Bergier et al. (2013b) $\mathrm{N}_{2} \mathrm{O}$ emissions (2.43-2.48\% of the total $\mathrm{N}$ inputs).

b Based on Eggleston et al. (2006) (Tier 1) $\mathrm{N}_{2} \mathrm{O}$ emissions ( $1 \%$ of the total $\mathrm{N}$ inputs).

c On March 2014, the fertigation in parcel D was purposely made with a 5-fold concentrated, dewatered effluent.

emergy" (seJ.g-1) for material flows. Emergy also can be expressed in emdollars, defined as the emergy supporting the generation of one unit of economic product (expressed as currency or money) (Odum, 1996).

Solar energy, rain and wind are interrelated flows of nature derived from the functioning of the biosphere, whose UEV are obtained by converting energy to emergy except for solar energy UEV that, by definition, is 1.00 (Odum et al., 2000). For this study, sun, wind and rainfall flows are relative to the local data for the pilot farm location (EOSWEB, 2014). In addition to these natural flows, the use of resources from other biological systems or ecosystems, as it is the case for nutrients, are also considered and the related UEV are obtained by the emergy analysis of the production system.
For materials purchased from the industrial economy, given the fact that the production processes are similar in different countries, the respective UEV is obtained by the emergy analysis of the process. For economic services, namely labor, administration, public services, fees and taxes, UEV are obtained by the ratio between emergy and Gross Domestic Product (emergy/GDP) for the country of reference in the reference year. Given the complex interaction processes for the renewable emergy flows, only the major flow of nature (solar energy, wind or rain) is considered in the calculations in order to avoid double accounting while for the flows related to the use of resources from other systems or ecosystems all of them are accounted for. After calculating emergy flows, a set of indicators is obtained to evaluate the system's performance concerning
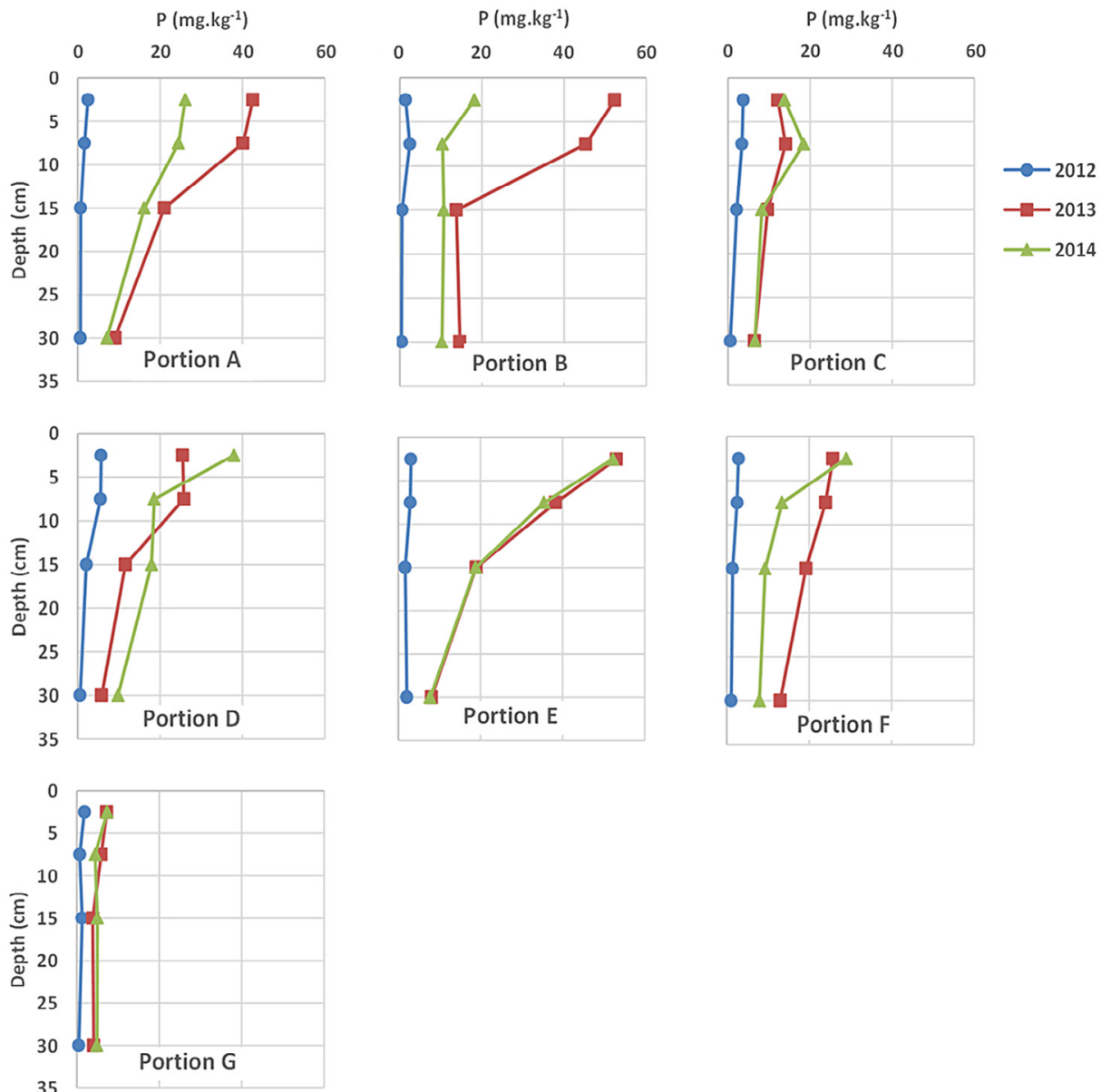

Fig. 4. P concentration at different soil depths for each portion of the pilot farm. 
renewable resources usage and non-renewable resources dependence. Consequently, the system's renewability and its impacts on the environment and local economy can be analyzed and compared with alternative systems.

The slightly modified emergy methodology adopted in this study includes externalities (GHG emissions, infiltration of contaminants and excess of nutrients) as additional services (Ortega et al., 2005). Direct GHG emissions and other externalities, like contaminant infiltration and nutrient excess, are usually not considered in the emergy accounting of agricultural systems. Without accounting of those externalities, systems that do not treat animal manure present better emergy indicators because of no cost for building and machinery. Alternatively, systems with an anaerobic biodigester show a worse performance by virtue of economy flows for construction and operation. Economy flows evidence the dependence on external resources but do not allow the evaluation of nutrient management and GHG emissions reduction. GHG Unit Emergy Values (UEV) were obtained from Lu et al. (2012) and Campbell et al. (2014). The latter GHG UEV were obtained by means of the emergy accounting of biogeochemical cycles of active elements and composts.

In general, the analysis of the emergy indicators is done by comparison with similar systems that can, however, present different resource exploitation practices and management that modify the values of renewable or non-renewable flows and therefore the emergy indicators. A good comparison is the transformities of the system's outputs that, because of the energy hierarchy, are expected to be in the same order of magnitude.

The emergy indicators (Odum, 1996) used to assess the integrated swine-crop-pasture-eucalyptus system are described below.

- Renewability (\%R): ratio between renewable resources emergy flow and total emergy flow supporting the system, it can be interpreted as a measure of the sustainability. The higher this indicator the lower the dependence on external resources and the higher the system's renewability.

- Emergy Exchange Ratio (EER): proportion of the received emergy for the system outputs and the delivered emergy (accounted as the input flows) in a transaction. It measures if the trade is fair enough to compensate nature's efforts used by the system and it allows verifying whether there is benefit or not in the interchange with the market. The value 1.00 for EER means that the trade is fair and above this value, the system moves away from equilibrium.

- Emergy Investment Ratio (EIR): ratio between the economy resources emergy flow and the renewable and non-renewable resources emergy flow. The two last flows are usually considered as a free resource in nature and are not accounted in the common sustainability assessments. It evaluates whether the emergy invested in a process is well used, in comparison with alternatives, i.e., it is a measure of the economic investment needed to the production. EIR allows the discussion of the economic feasibility of a process and the evaluation of how much a process utilizes well the invested emergy. Large values of EIR indicate advanced regional development.

- Environmental Loading Ratio (ELR): ratio between the nonrenewable resources emergy flows and the renewable flow. It is a measure of the pressure of a process on the environment and evaluates the ecosystem stress. The higher this indicator the higher is the environmental stress.

The emergy indicators for agricultural integrated systems including swine that have been previously evaluated are presented in Table 3. The range of variation of the emergy indicators among the different systems is explained by the differences between them (integrated or not), by the manure management adopted and by the inclusion or not of externalities in emergy calculations.
Table 3

Emergy indicators for agricultural and swine systems.

\begin{tabular}{|c|c|c|c|c|c|}
\hline System description & Reference & $\% R$ & EER & EIR & ELR \\
\hline $\begin{array}{l}\text { Integrated system (swine, } \\
\text { corn, dairy cattle), with } \\
\text { anaerobic biodigester, } \\
\text { emergy assessment with } \\
\text { externalities. }\end{array}$ & Teixeira, 2012 & 7.83 & 0.09 & 36.79 & 11.78 \\
\hline $\begin{array}{l}\text { Integrated system (swine, } \\
\text { corn), without anaerobic } \\
\text { biodigester, emergy } \\
\text { assessment with } \\
\text { externalities. }\end{array}$ & Teixeira, 2012 & 5.11 & 0.29 & 104.65 & 18.58 \\
\hline $\begin{array}{l}\text { Non-integrated system (only } \\
\text { swine in a quasi-wild } \\
\text { state), without anaerobic } \\
\text { biodigester, emergy } \\
\text { assessment without } \\
\text { externalities. }\end{array}$ & $\begin{array}{l}\text { Rugani et al., } \\
2011\end{array}$ & 21.03 & - & 3.67 & 3.76 \\
\hline $\begin{array}{l}\text { Non-integrated system (only } \\
\text { intensive swine), without } \\
\text { anaerobic biodigester, } \\
\text { emergy assessment } \\
\text { without externalities. }\end{array}$ & $\begin{array}{l}\text { Rugani et al., } \\
2011\end{array}$ & 2.15 & - & 44.07 & 45.56 \\
\hline $\begin{array}{l}\text { Integrated system (swine- } \\
\text { corn-fish), without } \\
\text { anaerobic biodigester, } \\
\text { emergy assessment } \\
\text { without externalities. }\end{array}$ & $\begin{array}{l}\text { Cavalett et al., } \\
2006\end{array}$ & 24.00 & 6.80 & 2.28 & 3.13 \\
\hline
\end{tabular}

Beyond the usual indicators, two more related to soil loss (Cohen et al., 2006) were evaluated.

- Fraction of Use Soil Erosion (FUSE): ratio between the soil loss emergy flow and the total emergy flow supporting the system. It is expressed as \% of the use arising from erosion and measures the soil loss in emergy for a regional system.

- Soil Intensity of Agriculture (SIA): ratio between the agricultural products emergy (derived from the use of the soil) and the soil loss emergy flow. It represents the cost-benefit of the soil use.

In this paper, GHG emissions from agriculture, which include soil emissions from field data and other emissions namely: enteric fermentation, manure emissions of $\mathrm{CH}_{4}$ and $\mathrm{N}_{2} \mathrm{O}$ and $\mathrm{NH}_{3}$ volatilization from mineral fertilizer and/or fertigation (see emergy tables and calculations notes in Appendix: Supplementary materials for each different system), were accounted for in the emergy assessment aiming to understand and discuss its impact on emergy indicators. For this purpose, initially, two systems were evaluated, with and without the inclusion of externalities in the emergy accounting (refer to Appendix A). The description and assumptions for both systems are:

(a) The first system presents the usual tillage agriculture without the anaerobic biodigester system and it is based on intense use of synthetic fertilizers. This system is very dependent on external resources (materials from the economy) and presents low or no soil conservation techniques (tillage and no terraces), as consequence high soil loss, and the system is prone to soil degradation in the long term. Nutrient recycling is extremely low or absent for this agriculture model. GHG emissions are high and the estimates were gathered from scientific literature for Brazilian systems (refer to Appendix $\mathrm{B}$ and $\mathrm{H} 1$ ).

(b) The second system corresponds to the pilot-farm with reduced tillage and equipped with the anaerobic biodigester. This system corresponds to the transition to low carbon agriculture. A reduction in synthetic fertilizers is considered with 
a substitution by organic fertilizer, favoring nutrient recycling. Soil conservation techniques (terrace, no-tillage, crop rotation) are also considered thus the soil loss was reduced. This system includes the electric power surplus sales and a stormwater recovery system that mitigates groundwater consumption. The stormwater recovery system is a local experience already established in some farms that is being encouraged in the region as a water management practice. It is based on rain collection in the swine shed roofs by gravity to supply a pond capable of storing water for whole year consumption for swine shed cleaning and animal watering. Refer to Appendix $\mathrm{C}$ and $\mathrm{H} 2$ for all the calculations, references and assumptions.

Further sustainability assessments for the development of the integrated swine-crop-pasture-eucalyptus system over 4 years were also performed:

(c) Integrated swine-crop-pasture-eucalyptus system (ISCPE, year I) with cultivated pasture in rotation with crops and rows of eucalyptus with no-tillage management. The main land occupation is still for crops that present higher productivity because of soil management improvements and soil loss reductions due to notillage and less chemical use in the system. In addition, rotational grazing is adopted and its intensity is managed to keep pasture height in $20 \mathrm{~cm}$. Refer to Appendix D and H3 for all the calculations, references and assumptions.

(d) The second year of the integrated swine-crop-pastureeucalyptus system (ISCPE, year II). While the livestock occupation is higher than in the year before and enteric GHG emissions are higher, the system is occupied mainly by pasture and the use of synthetic fertilizer is absent, only organic fertilizer is applied and the nutrient recycling is intense. Soil loss is much lower than in the years before and by virtue of soil conservation techniques we assumed that the soil is improved and that the ecosystem services related to water and carbon cycles present higher values. Refer to Appendix E and $\mathrm{H} 4$ for all the calculations, references and assumptions. (e) The third year of the integrated swine-crop-pastureeucalyptus system (ISCPE, year III). In this system, the assumption of a soil improvement by virtue of continuous soil conservation techniques employment keeps reducing soil loss and improving ecosystem services recovery (related to water and carbon cycles). Refer to Appendix F and H5 for all the calculations, references and assumptions.

(f) The fourth year of the integrated swine-crop-pastureeucalyptus system (ISCPE, year IV). The soil improvement has allowed the soil loss to be the lowest value and the ecosystems services are the highest among all the previous systems. Refer to Appendix G and H6 for all the calculations, references and assumptions.

The integrated swine-crop-pasture-eucalyptus system also produces ecosystem services as an output, of which valuing for the study region was based on Watanabe and Ortega (2014).

The general systems diagram (using energy language symbols from Odum, 1996) for ISCPE, presented in Fig. 5 (simplified diagram) and Fig. 6 (complete diagram), allows the identification of the interactions between nature and economy flows for the system functioning. All the external resources (renewable and nonrenewable, natural and from the economy) are placed outside the system boundary and their respective flows are connected to several elements inside the box (and represent where each one them are allocated in the system's interactions). It is necessary to observe that, despite the system boundary, it is not a closed system. The connection of the inside elements with the outside elements is captured in the diagram to represent an open system.

The photosynthetic elements of the agroecosystem, placed inside the system boundary, on the left side, receive the external resources flows and are directly connected to their respective storage of products and with the soil storage. For the natural reserve, the main products are soil, organic matter and clean water that play a relevant role in the biodiversity and positively interact with the ecosystem services (hydrological and carbon services). The system under study does not have the natural reserve inside its boundary; anyway, natural reserve is represented in the diagram in order to allow the

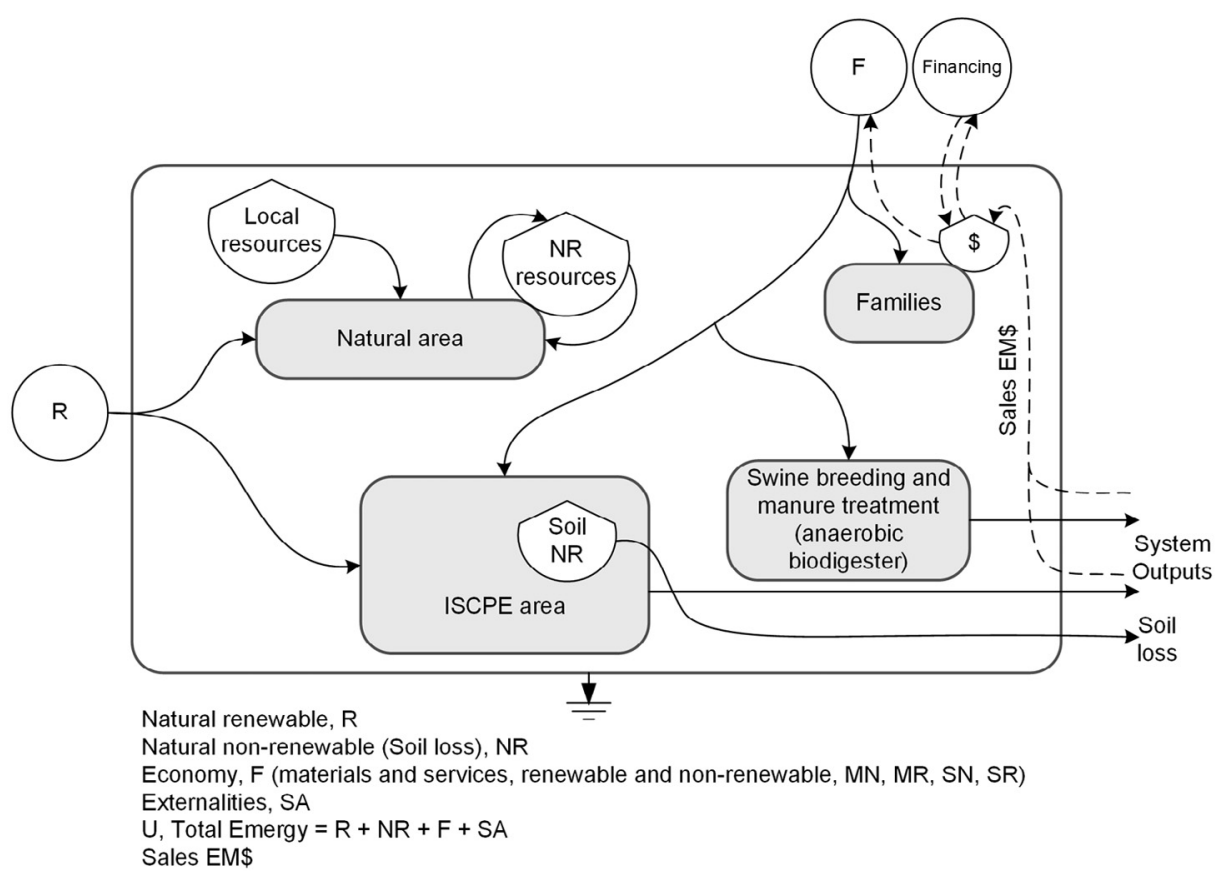

Fig. 5. Pilot farm simplified systems diagram. 


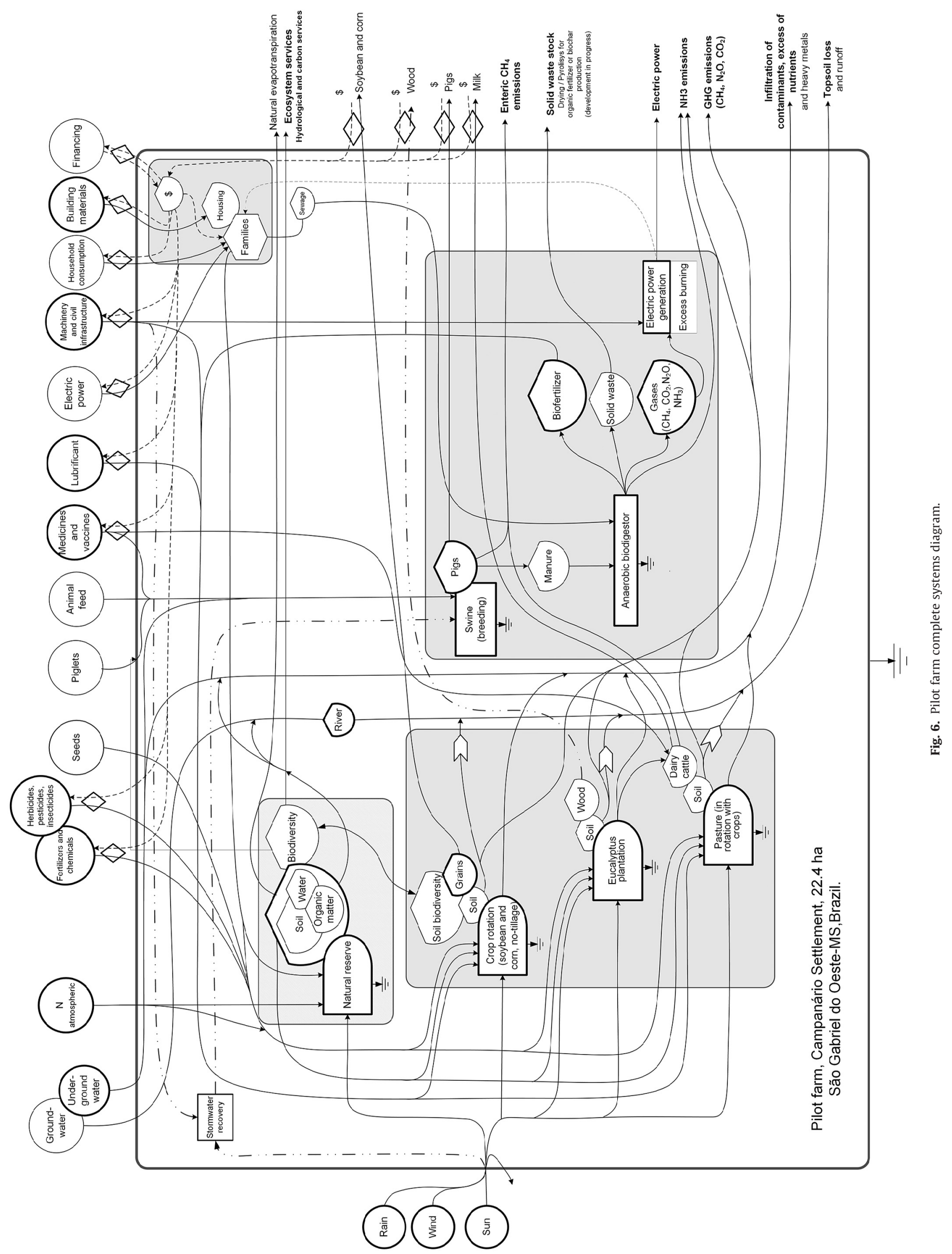


Table 4

Systems productivity and energy, materials, GHG and externalities flows.

\begin{tabular}{|c|c|c|c|c|c|c|c|}
\hline & & $\begin{array}{l}\text { Tillage } \\
\text { system }\end{array}$ & $\begin{array}{l}\text { Reduced tillage with } \\
\text { manure biodigestion }\end{array}$ & $\begin{array}{l}\text { ISCPE }^{\mathrm{a}} \text {, } \\
\text { year I }\end{array}$ & $\begin{array}{l}\text { ISCPE, } \\
\text { year II }\end{array}$ & $\begin{array}{l}\text { ISCPE, } \\
\text { year III }\end{array}$ & $\begin{array}{l}\text { ISCPE, } \\
\text { year IV }\end{array}$ \\
\hline \multicolumn{8}{|l|}{ Products } \\
\hline Alive pigs & heads $\cdot$ ha $^{-1} \cdot$ year $^{-1}$ & 268.00 & 268.00 & 268.00 & 268.00 & 268.00 & 268.00 \\
\hline Cattle stocking & heads $\cdot$ ha $^{-1} \cdot$ year $^{-1}$ & 2.00 & 2.00 & 2.00 & 10.00 & 10.00 & 10.00 \\
\hline Soybean & bags of $60 \mathrm{~kg} \cdot \mathrm{ha}^{-1}$ & 55.00 & 63.00 & 85.00 & & & \\
\hline Corn & bags of $60 \mathrm{~kg} \cdot \mathrm{ha}^{-1}$ & 67.00 & 106.00 & 168.00 & & & \\
\hline Milk & 1.day ${ }^{-1} \cdot$ head $^{-1}$ & 8.00 & 11.66 & 11.66 & 11.66 & 11.66 & 11.66 \\
\hline Hydrological services & EM\$ $\$$ ha $^{-1} \cdot$ year $^{-1}$ & 64.90 & 115.81 & 145.98 & 152.00 & 152.00 & 152.00 \\
\hline Carbon services & EM\$ $\$$ ha $^{-1} \cdot$ year $^{-1}$ & 10.10 & 43.25 & 34.07 & 52.24 & 52.24 & 52.24 \\
\hline Electric power surplus & $\mathrm{kW} \cdot \mathrm{year}^{-1}$ & & $5.26 \mathrm{E}+05$ & $5.24 \mathrm{E}+05$ & $5.25 \mathrm{E}+05$ & $5.25 \mathrm{E}+05$ & $5.25 \mathrm{E}+05$ \\
\hline \multicolumn{8}{|l|}{ Management } \\
\hline Soil loss & $\mathrm{kg} \cdot \mathrm{ha}^{-1} \cdot \mathrm{year}^{-1}$ & $2.05 \mathrm{E}+05$ & $1.52 \mathrm{E}+05$ & $9.85 \mathrm{E}+04$ & $3.03 \mathrm{E}+04$ & $9.09 \mathrm{E}+03$ & $4.41 \mathrm{E}+03$ \\
\hline Synthetic fertilizer usage & & High & Reduced & Low & None & None & None \\
\hline Pasture height ${ }^{\mathrm{b}}$ & $\mathrm{cm}$ & Unruled & Unruled & 20 & 20 & 20 & 20 \\
\hline Grazing system ${ }^{\mathrm{b}}$ & & Continuous & Continuous & Rotational & Rotational & Rotational & Rotational \\
\hline No-tillage & & No & Yes & Yes & Yes & Yes & Yes \\
\hline $\begin{array}{l}\text { Soil conservation } \\
\text { techniques }\end{array}$ & & None & Low & Medium & High & High & High \\
\hline Fertigation & & No & Partial & Partial & Full & Full & Full \\
\hline $\begin{array}{l}\text { Manure treatment } \\
\text { (biodigester and } \\
\text { effluent processing } \\
\text { technologies) }\end{array}$ & & No & Yes & Yes & Yes & Yes & Yes \\
\hline Stormwater recovery & & No & Yes & Yes & Yes & Yes & Yes \\
\hline \multicolumn{8}{|l|}{ Use of inputs } \\
\hline Pest control & kg.ha ${ }^{-1} \cdot$ year $^{-1}$ & 11.00 & 11.00 & 11.00 & 2.61 & 2.61 & 2.61 \\
\hline Seeds (GMO) & kg.ha ${ }^{-1} \cdot$ year $^{-1}$ & 118.00 & 118.00 & 118.00 & 20.00 & 20.00 & 20.00 \\
\hline Medicines and vaccines & US\$ $\$$ ha $^{-1} \cdot$ year $^{-1}$ & 148.84 & 148.84 & 148.84 & 153.93 & 153.93 & 153.93 \\
\hline $\mathrm{P}$ & kg.ha ${ }^{-1} \cdot$ year $^{-1}$ & 142.00 & 131.00 & 87.00 & & & \\
\hline $\mathrm{N}$ & $\mathrm{kg} \cdot \mathrm{ha}^{-1} \cdot \mathrm{year}^{-1}$ & 99.00 & 96.00 & 53.00 & & & \\
\hline $\mathrm{K}$ & $\mathrm{kg} \cdot \mathrm{ha}^{-1} \cdot \mathrm{year}^{-1}$ & 270.00 & 250.00 & 168.00 & & & \\
\hline Urea & $\mathrm{kg} \cdot \mathrm{ha}^{-1} \cdot \mathrm{year}^{-1}$ & & & 150.00 & & & \\
\hline Limestone (CaO) & $\mathrm{kg} \cdot \mathrm{ha}^{-1} \cdot \mathrm{year}^{-1}$ & $2,000.00$ & $1,200.00$ & $1,200.00$ & & & \\
\hline \multicolumn{8}{|l|}{ Materials } \\
\hline Cement & $\mathrm{kg} \cdot \mathrm{ha}^{-1} \cdot \mathrm{year}^{-1}$ & 213.52 & 213.52 & 213.52 & 213.52 & 213.52 & 213.52 \\
\hline Steel & $\mathrm{kg} \cdot \mathrm{ha}^{-1} \cdot \mathrm{year}^{-1}$ & 110.00 & 115.36 & 115.36 & 115.36 & 115.36 & 115.36 \\
\hline Copper & $\mathrm{kg} \cdot \mathrm{ha}^{-1} \cdot \mathrm{year}^{-1}$ & & 0.69 & 0.69 & 0.69 & 0.69 & 0.69 \\
\hline Cast iron & kg.ha ${ }^{-1} \cdot$ year $^{-1}$ & & 28.91 & 28.91 & 28.91 & 28.91 & 28.91 \\
\hline Lubricant & $\mathrm{J} \cdot \mathrm{ha}^{-1} \cdot$ year $^{-1}$ & & $2.79 \mathrm{E}+09$ & $2.79 \mathrm{E}+09$ & $2.79 \mathrm{E}+09$ & $2.79 \mathrm{E}+09$ & $2.79 \mathrm{E}+09$ \\
\hline Aluminum alloy & $\mathrm{kg} \cdot \mathrm{ha}^{-1} \cdot$ year $^{-1}$ & & 0.34 & 0.34 & 0.34 & 0.34 & 0.34 \\
\hline PVC & $\mathrm{kg} \cdot \mathrm{ha}^{-1} \cdot$ year $^{-1}$ & & 12.40 & 12.40 & 12.40 & 12.40 & 12.40 \\
\hline \multicolumn{8}{|l|}{ Externalities } \\
\hline $\mathrm{CH}_{4}$ emissions & $\mathrm{kg} \cdot \mathrm{ha}^{-1} \cdot \mathrm{year}^{-1}$ & $2,427.71$ & 370.98 & 370.98 & 457.60 & 457.60 & 457.60 \\
\hline $\mathrm{N}_{2} \mathrm{O}$ emissions & kg.ha ${ }^{-1} \cdot$ year $^{-1}$ & $707.01^{c}$ & 6.63 & 6.63 & 8.55 & 8.55 & 8.55 \\
\hline $\mathrm{C}-\mathrm{CO}_{2}$ emissions & kgC.ha ${ }^{-1} \cdot$ year $^{-1}$ & $7,853.33$ & $7,648.11$ & $5,975.80$ & $5,924.50$ & $5,924.50$ & $5,616.46$ \\
\hline $\mathrm{NH}_{3}$ & $\mathrm{~kg} \cdot \mathrm{ha}^{-1} \cdot \mathrm{year}^{-1}$ & 163.46 & 138.95 & 134.81 & 167.64 & 167.64 & 167.64 \\
\hline $\begin{array}{l}\text { Infiltration of } \\
\text { contaminants }\end{array}$ & US\$.ha ${ }^{-1} \cdot$ year $^{-1}$ & 25.01 & 17.55 & 17.55 & 17.55 & 17.55 & 17.55 \\
\hline Excess of nutrients & US\$ $\cdot$ ha $^{-1} \cdot$ year $^{-1}$ & 0.88 & & & & & \\
\hline
\end{tabular}

a ISCPE: integrated swine-crop-pasture-eucalyptus.

b For no-till integrated systems, pasture management adheres to the newest research and recommendations (Kunrath et al., 2014; Silva et al., 2014).

c Calculated using table 3A2, tier 1 (Eggleston et al., 2006).

understanding of its ecosystem role. For the agricultural elements, the interactions with the river and the groundwater are represented by internal flows linked to the water resources flows (represented as groundwater and underground water) that flows outside the system as externalities (topsoil loss and infiltration and/ or excess of nutrients).

All the system's outputs (or goods) produced by the agroecosystem are placed outside on the right of the diagram; some of them involves money transactions whose flows come back inside the system to an internal storage that supports all the purchases for the materials from the economy and the insider families living. The anaerobic biodigester requires several flows from the economy as well as the electric power generation and the stormwater recovery systems. Biodigester outputs are all considered in the diagram within their respective destination for liquid or solid organic fertilizer and $\mathrm{CH}_{4}$ conversion into electric power. Regarding the GHG emissions from enteric fermentation, from soil and from the biodigester pond, all of them are placed as outputs, here considered as externalities that require additional services to be "treated". This is the reason to consider them and other externalities in the emergy accounting.

The entry of animal feed in the system has the peculiar characteristic of being obtained by an exchange process with the local agricultural cooperative, "Cooperativa Agropecuária de São Gabriel do Oeste" (COOASGO). The associated producers deliver corn to the cooperative and receive the animal feed processed paying only the cost of processing plus the excess of feed in case of the feed conversion exceeding the ideal. COOASGO also intermediates the meat and grains trade with the market in order to assure scope and economy scales for sales in a beneficial way for the associated producers.

Productivity information, fertilizers, chemicals, materials consumption, GHG emissions and other externalities flows for (a) to (f) systems previously described are summarized in Table 4. The emergy baseline and all the energy, materials and emergy flows 
calculated in the emergy tables for each system and the related calculation notes, references and assumptions are available in Appendix: Supplementary materials.

\section{Results and discussion}

The comparison of soil $\mathrm{N}_{2} \mathrm{O}$ emissions of field measurements with other estimates from the scientific literature (Table 2) demonstrate that neither module tier 1 from Eggleston et al. (2006) nor a more recent field-based model (Bergier et al., 2013b) can precisely estimate $\mathrm{N}_{2} \mathrm{O}$ flux for the studied portions. Some of the observed variability in soil GHG exchanges, in general, can be associated with other unconsidered factors. Field data suggest that there is no clear relationship between fertigation and stimulation of oxidation of soil organic carbon (SOC) and there is no evidence of priming effect. The real priming effect versus the apparent one and their mechanisms remains controversial (Blagodatskaya and Kuzyakov, 2008; Ramirez, 2007), mainly because of priming effect involves several processes related to the succession of microbial community and its functions. Despite the foregoing, Ren et al. (2014) have demonstrated that the management of organic manure (according to root-zone $\mathrm{N}$ management) did not influence the accumulation of $\mathrm{SOC}$ and total $\mathrm{N}$ in soil while promoted a beneficial reduction in $\mathrm{N}$ losses.

A clear example is the $\mathrm{N}$ overload by fertigation in portion $\mathrm{D}$ that did not stimulate $\mathrm{CO}_{2}$ emissions (Table 2). Alternatively, fertigation seems to stimulate consumption of $\mathrm{CH}_{4}$ by the soils, but, in contrast, stimulates the emission of $\mathrm{N}_{2} \mathrm{O}$ in particular at high doses. Table 2 data evaluation suggests that fertigation overload should be avoided to mitigate GHG emissions due to $\mathrm{N}_{2} \mathrm{O}$. Nonetheless, areas $\mathrm{F}$ and $\mathrm{G}$ that received only mineral fertilizers showed large $\mathrm{N}$ gaseous emissions. Hence, it is likely that other soil properties and its historical use are challenging to better differentiate gaseous emissions as a function of mineral and/or organic fertilizer inputs.

Regarding micro $(\mathrm{Zn}, \mathrm{Cu})$ and macronutrients $(\mathrm{P}, \mathrm{K})$ at different soil depths, the lower values in the deeper layers suggest that the nutrient infiltration for the timespan of the measurements is small. The Cerrado soil is unfertile and most of the nutrients are absorbed by the radicular system of the cultivated plants. Because of this, for the emergy assessment of the integrated systems with best practices, the assumption is the lack of accumulation or infiltration of nutrients in the upper soil layers. The comparison of portions $\mathrm{C}$ and $\mathrm{D}$, whose treatments were mineral fertilizer + fertigation and fertigation only, respectively, does not indicate that fertigation has led to greater accumulation of nutrients.

In particular, $\mathrm{P}$ is the most critical nutrient whose excess in soil may create a risk of $P$ losses by means of soil erosion, runoff and the associated eutrophication of surface waters (Bai et al., 2013). In fact, field data indicate that total $\mathrm{P}$ is the only nutrient that consistently increases over time at all the soil depths, for synthetic and/ or organic treatments (Fig. 4). Gatiboni et al. (2014) have developed a method (based on soil clay contents) to obtain the critical environmental limit for P addition in soil applicable for all the various fertilizers but valid for soil erosion controlled situations. The P critical limit for studied soil, calculated according to Gatiboni et al. (2014) method is $72 \mathrm{mg} \cdot \mathrm{kg}^{-1}$. It is therefore recommended to monitor total $\mathrm{P}$ in soil, and, if necessary, it would be advisable to export a fraction of the digested swine manure as organic compost or biochar to mitigate soil $\mathrm{P}$ accumulation or leaching to the surrounding aquatic resources.

Turning to the emergy assessment of integrated crop-livestock systems, the environmental performance of the systems (a) and (b), described in Section 2.3, indicate that the adoption of anaerobic biodigestion of manure and its related GHG mitigation contributes to the reduction of the Renewability index, from $4.85 \%$ to $8.78 \%$. Also, this results in a lower Environmental Loading Ratio (ELR), from 19.61 to 10.38 , in comparison with the usual system with the disposal of manure in nature (Table 5).

Both analyses were conducted with and without externalities related to GHG emissions. The exclusion of the externalities produces larger Renewability and a lower ELR for the usual system (a). However, this does not mean that the system lacking both manure treatment and GHG mitigation is appropriate to meet the demands and expectations of a new sustainable agriculture model. Hence, the system analysis without externalities can provide misleading conclusions as the adoption of manure management technology (anaerobic biodigester) is rather renewable and causes more pressure over the environment than the conventional manure disposal without treatment processes that emit more GHG.

The reduction of GHG emissions from manure is the main strategy that contributes to a twofold superior renewability and a twofold lower ELR for the reduced tillage system. The observed results show that this system is heavily dependent on economic resources. Although the reduction of GHG emissions is large, the physical structure necessary for the anaerobic biodigester system and generator to produce power influences the overall emergy indicators. As the emergy assessment is performed in a yearly basis, all the inputs for the physical structure are systematically accounted to properly address the pressure of these non-renewable flows in the system, so it is important to notice that there will be a pay-off over time of usage. Nonetheless, the entire processes of power generation and fertigation are completely driven by renewable energy, but the consideration of negative externalities allows a better assessment of GHG balance.

Ecosystem services and power sales are included in the outputs of the reduced tillage system. The value of Emergy Exchange Ratio (EER) above 1 suggests a fair exchange from the point of view of the farmers. However, it does not necessarily mean that they are paying for the produced externalities. In any case, even if the government sets a policy of payments for environmental impacts, the producer will continue to receive a fair exchange and the activity seems to remain economically interesting. Despite the high stocking ratio of 268 head per hectare, the indicators of the reduced tillage system show a better global performance compared with the usual system. This result can be attributed to the reduction of GHG emissions and to the power export to distributed smart-grids.

Emergy flows and indicators for all the six systems are presented in Table 6 . The performance of emergy indicators during the transition from conventional agriculture to 4-year integrated swine-crop-pasture-eucalyptus system is shown in Fig. 7.

Table 5

Emergy indicators for conventional system and reduced tillage with anaerobic biodigester system.

\begin{tabular}{|c|c|c|c|c|c|}
\hline \multirow[t]{2}{*}{ Emergy indicators } & & \multicolumn{2}{|c|}{ With externalities } & \multicolumn{2}{|c|}{ Without externalities } \\
\hline & & $\begin{array}{l}\text { Tillage } \\
\text { system }\end{array}$ & $\begin{array}{l}\text { Reduced tillage with } \\
\text { manure biodigestion }\end{array}$ & $\begin{array}{l}\text { Tillage } \\
\text { system }\end{array}$ & $\begin{array}{l}\text { Reduced tillage with } \\
\text { manure biodigestion }\end{array}$ \\
\hline \% Renewability & $(\mathrm{R}+\mathrm{MR}+\mathrm{SR}) / \mathrm{U}$ & $4.85 \%$ & $8.78 \%$ & $8.71 \%$ & $9.12 \%$ \\
\hline EIR - emergy investment ratio & $(\mathrm{SA}+\mathrm{MN}+\mathrm{SN}) /(\mathrm{R}+\mathrm{MR}+\mathrm{SR}+\mathrm{NR})$ & 5.33 & 3.25 & 2.53 & 3.09 \\
\hline ELR - environmental load ratio & $(\mathrm{NR}+\mathrm{MN}+\mathrm{SN}+\mathrm{SA}) /(\mathrm{R}+\mathrm{MR}+\mathrm{SR})$ & 19.61 & 10.38 & 10.48 & 9.97 \\
\hline EER - emergy exchange ratio & U/Sales EM\$ & 1.87 & 0.90 & 1.04 & 0.82 \\
\hline
\end{tabular}


Table 6

Emergy flows and indicators.

\begin{tabular}{|c|c|c|c|c|c|c|c|}
\hline & & $\begin{array}{l}\text { Tillage } \\
\text { system }\end{array}$ & $\begin{array}{l}\text { Reduced tillage with } \\
\text { manure biodigestion }\end{array}$ & $\begin{array}{l}\text { ISCPE, } \\
\text { year I }\end{array}$ & $\begin{array}{l}\text { ISCPE, } \\
\text { year II }\end{array}$ & $\begin{array}{l}\text { ISCPE, } \\
\text { year III }\end{array}$ & $\begin{array}{l}\text { ISCPE, } \\
\text { year IV }\end{array}$ \\
\hline \multicolumn{8}{|l|}{ Emergy flows } \\
\hline Natural renewable - $\mathrm{R}$ & seJ.ha ${ }^{-1} \cdot$ year $^{-1}$ & $3.02 \mathrm{E}+15$ & $2.86 \mathrm{E}+15$ & $2.86 \mathrm{E}+15$ & $2.86 \mathrm{E}+15$ & $2.86 \mathrm{E}+15$ & $2.86 \mathrm{E}+15$ \\
\hline Natural non-renewable (soil loss) - NR & seJ.ha ${ }^{-1} \cdot$ year $^{-1}$ & $5.97 \mathrm{E}+16$ & $4.42 \mathrm{E}+16$ & $2.87 \mathrm{E}+16$ & $8.84 \mathrm{E}+15$ & $2.65 \mathrm{E}+15$ & $1.29 \mathrm{E}+15$ \\
\hline Economy - MN, MR, SN, SR & seJ.ha ${ }^{-1} \cdot$ year $^{-1}$ & $1.42 \mathrm{E}+16$ & $8.06 \mathrm{E}+15$ & $8.12 \mathrm{E}+15$ & $3.72 \mathrm{E}+15$ & $3.72 \mathrm{E}+15$ & $3.72 \mathrm{E}+15$ \\
\hline Externalities - SA & seJ.ha ${ }^{-1} \cdot$ year $^{-1}$ & $2.41 \mathrm{E}+17$ & $1.10 \mathrm{E}+16$ & $1.09 \mathrm{E}+16$ & $1.34 \mathrm{E}+16$ & $1.34 \mathrm{E}+16$ & $1.33 \mathrm{E}+16$ \\
\hline $\mathrm{U}$ - total emergy & seJ.ha ${ }^{-1} \cdot$ ano $^{-1}$ & $3.18 \mathrm{E}+17$ & $6.61 \mathrm{E}+16$ & $5.06 \mathrm{E}+16$ & $2.88 \mathrm{E}+16$ & $2.26 \mathrm{E}+16$ & $2.11 \mathrm{E}+16$ \\
\hline Sales EM\$ & EM\$.ha ${ }^{-1} \cdot$ year $^{-1}$ & $5.23 \mathrm{E}+17$ & $6.04 \mathrm{E}+17$ & $6.28 \mathrm{E}+17$ & $6.63 \mathrm{E}+17$ & $6.63 \mathrm{E}+17$ & $6.63 \mathrm{E}+17$ \\
\hline \multicolumn{8}{|l|}{ Emergy indicators } \\
\hline \%Renewability & Dimensionless & \multicolumn{6}{|c|}{$(\mathrm{R}+\mathrm{MR}+\mathrm{SR}) / \mathrm{U}$} \\
\hline EIR - emergy investment ratio & Dimensionless & \multicolumn{6}{|c|}{$(\mathrm{SA}+\mathrm{MN}+\mathrm{SN}) /(\mathrm{R}+\mathrm{MR}+\mathrm{SR}+\mathrm{NR})$} \\
\hline ELR - environmental loading ratio & Dimensionless & \multicolumn{6}{|c|}{$(\mathrm{NR}+\mathrm{MN}+\mathrm{SN}+\mathrm{SA}) /(\mathrm{R}+\mathrm{MR}+\mathrm{SR})$} \\
\hline EER - emergy exchange ratio & Dimensionless & \multicolumn{6}{|c|}{ (U/EM\$Sales) } \\
\hline FUSE - fraction of use soil erosion & Dimensionless & \multicolumn{6}{|c|}{ (Soil loss emergy/U) } \\
\hline SIA - soil intensity of agriculture & Dimensionless & \multicolumn{6}{|c|}{ (EM\$ of agricultural sales/Soil loss emergy) } \\
\hline
\end{tabular}

In comparison with Teixeira (2012) results for integrated systems operating with anaerobic biodigester and externalities accounting, the Renewability and ELR here obtained are very close expectations by virtue of the systems characterization. Conversely, EER and EIR differ because of different economic aspects related to the regional characterization (Teixeira, 2012) developed the emergy assessment for the South region of Brazil).

Emergy indicators improved the results related to soil erosion, fraction of use soil erosion (FUSE) and soil intensity of agriculture (SIA) (Fig. 7), meeting the assumptions associated with integrated systems. Soil loss reduces along 4 years' timeframe by virtue of the beneficial effects of organic matter increasing and recovery of degraded areas (Galdino, 2012) leading the FUSE to a sharp cutback. Conversely, SIA rising reflects economic gains related to land-use and indicates that the integrated system becomes more efficient with time. In general, soil erosion is a hidden cost of the development of agricultural activities (Cohen et al., 2006). Soil erosion represents $19 \%$ of the total emergy use in the tillage system and in a recovered soil, after the rotation of crops and pastures for a few years (refer to ISCPE, year 4); it reaches about 6\% of the total emergy use.

Soil loss and reduction in externalities emergy flows are the main drivers for the higher \%Renewability and the lower ELR along the succession of more ecological agroecosystems, as observed for the systems designs and the timeframe under assessment. The rising EIR values suggest that the maturation of the ISCPE system provides a greater regional development in the mid-term.

Electric power generation and the possibility to export the surplus are good practices for Clean Development Mechanism. Although the electric power production does not have a pronounced effect on emergy indicators, the self-sufficiency and the energy surplus are indeed relevant for the general sustainability of the agricultural systems.
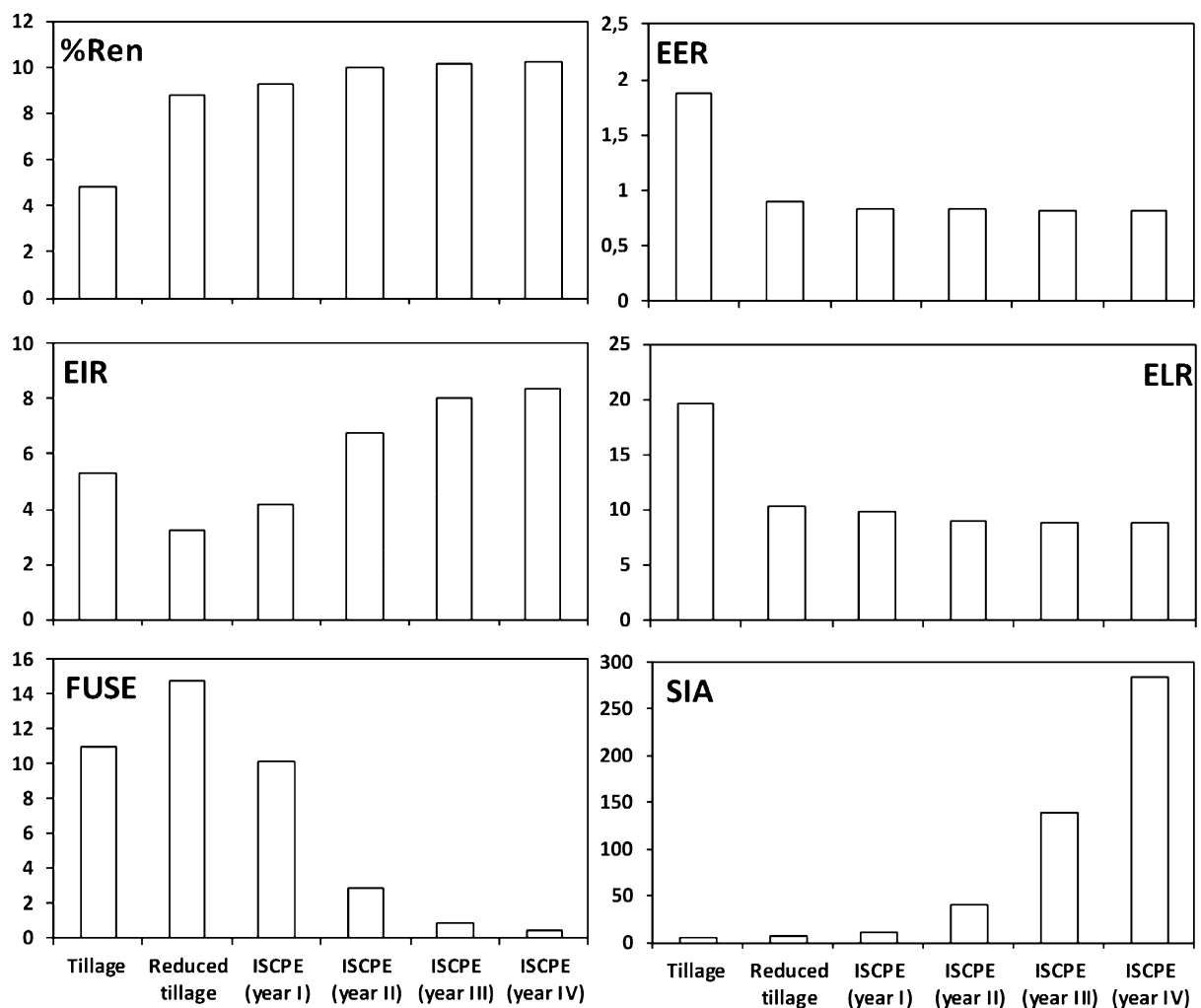

Fig. 7. Emergy indicators performance along the agricultural systems transition. 
Still with regard to economic aspects, the very low EER values for the integrated system mean that this agricultural system is beneficial to producers and there is a fair and balanced exchange. As previously discussed in the comparison of systems with and without externalities, this result suggests that even if a policy for environmental impacts payments was established, the producer still gets a fair deal and continues to generate an economically attractive activity.

The most important remark refers to the nutrient cycling and reduction in GHG emissions flows, in particular with regard to $\mathrm{N}$ and $\mathrm{P}$. Although the ISCPE shows higher $\mathrm{CH}_{4}$ and $\mathrm{N}_{2} \mathrm{O}$ fluxes related to the presence of more cattle in the agroecosystem, the reduceddependence on synthetic $\mathrm{N}$ and $\mathrm{P}$ and the partial replacement of them by organic fertilizer is an extremely important environmental management strategy. Bergier et al. (2012) have simulated soil carbon stock dynamics for three depths based on field data of farms fertigated for distinct timespans. They verified that after approximately 33 years of continuous adoption of best practices, the net primary production NPP $>0$, i.e., the incorporation of carbon in the soil (under well-managed pasture) exceeds the soil respiration rate. As a result, there is an increase in the soil carbon stock in the long term after about 30 years (Bergier et al., 2012).

In addition, solid fertilizer can be produced via digester drying/ dewatering or pyrolysis processing to obtain organic compost or biochar, respectively. A liquid-solid separating system was designed to produce biochar from biodigested swine manure (Bergier et al., 2013a, 2013b). Several studies suggest that some of the beneficial mechanisms of biochar in soil are the reduction of nutrient leaching, the mitigation of $\mathrm{N}_{2} \mathrm{O}$ emissions, improvement of soil cation exchange capacity and the increment of the ammonium ion $\left(\mathrm{NH}_{4}^{+}\right)$ stock that reduces ammonia $\left(\mathrm{NH}_{3}\right)$ volatilization due to adsorption processes (Clough et al., 2013). Therefore, the adoption of biochar to soils might enhance even more the advantage of ISCPE through the improvement of agronomic productivity and sustainability. Organic compost, biochar and liquid organic fertilizer could also be exported from the agroecosystem contributing to reduce $\mathrm{P}$ overload in soils and to minimize the external resources dependence, constituting a new business opportunity that creates a novel socioeconomic scenario for the region. It is possible to create an integration between swine farms that produce organic fertilizers and other farms that have not incorporated the technology. This is especially important for small farmers that lack financial opportunities, whose farm activity is horticulture, or other food focused operations.

A benchmarking of the best practices related to the pilot farm experience could be accomplished for the transition of several agroecosystems by means of a Clean Development Mechanism associated with the recovery of degraded areas, soil fertility improvement and power self-sufficiency, accordingly to the Brazilian Low Carbon Program. Regarding cattle ranching, it has been observed that the fertigated pasture allows raising about 10 times more heads per hectare (Cooasgo, unpublished data) than the national mean density that is 1 head per ha (IBGE, 2012). Furthermore, this sort of land management avoids the infiltration of contaminants, contributing to water quality conservation and, in particular, prevents eutrophication of water bodies (Bergier et al., 2014). The findings of this work can be useful for public policies related to sustainable land-use planning and management in rural areas of the Cerrado in general, improving social inclusion and mitigating potential impacts in several time-space scales by preventing soil erosion, maximizing internal nutrient recycling, and reducing the reliance on external and nonrenewable resources.

\section{Conclusions}

The challenge of future agriculture is its ability to diminish the reliance on nonrenewable resources. Such strong dependence emerged in the mid-20th century, after the end of the second war, when the Haber-Bosch synthesis (atmospheric N fixation) was diverted from explosive to food markets. In this work, we show that the intense use of fossil resources in the actual agribusiness can be somehow minimized as an accomplishment to reduce its impact on global warming and climate change. The ability to integrate livestock-crop production systems in a more sustainable way is key to achieving a larger share of renewable energy and materials in the farm level. Manure management is of vital importance in this context, creating the possibility to explore emerging renewable markets.

Swine manure management is well advanced and it can nowadays boost the productivity of other agribusiness sectors such as organic fertilizer, beef, milk, grain and other forestry products. We have shown that integrating swine manure management to other agribusiness sectors, despite of mitigating GHG, improves the renewability of the whole agroecosystem. The modified emergy assessment including externalities improves the understanding of integrated crop-livestock systems (ICLS) efficiency in internal recycling of nutrients and power conversion. The adoption of manure treatment in intensified agricultural systems can effectively contribute to enhanced environmental and economic performances.

GHG emissions accounting in Emergy Synthesis was crucial to achieve a realistic assessment of the studied agricultural system. Integrated crop-livestock systems can improve soil fertility and can lead to an efficient soil use and management able to mitigate GHG emissions toward a more sustainable agriculture in the long-term for the Brazilian Cerrado and other worldwide regions with similar soil and climate conditions. It is important to note that climate changes are already in course, therefore future studies in integrated livestock-crop production systems must consider the very likely extreme weather changes.

\section{Acknowledgements}

This work was partially funded by MCTI/CNPq/Repensa, Grant number 562441/2010-7, and Embrapa/Macroprograma 2, Grant number 02.11.05.002. Special thanks to João Vila dos Santos da Silva for the valuable assistance and for sharing his knowledge, expertise and information about the Paraguay River Basin and the Taquari River Basin. Thanks to Afonso Libero Rosalen, Ancionei Antônio Thebaldi, Carlos Shimata, Fausto Mariano, Jair Borgmann, Luiz Rieger, Rubia Rech, Thiago Goulart and Matheus Tschaen for the valuable support during the field data collection and organization for this paper and to the participant institutions, particularly, to the Ministry of Agriculture, Livestock and Food Supply (MAPA) and Federal University of Paraná (UFPR) that coordinates the Production Program for Integrated Farming Systems in Watersheds (PISA) and to the support given by COOASGO (São Gabriel do Oeste Agricultural Cooperative). The first author gratefully acknowledges the scholarship from the Coordination for the Improvement of Higher Education Personnel (CAPES, Brazil).

\section{Appendix: Supplementary material}

Supplementary data to this article can be found online at doi:10.1016/j.agsy.2014.11.004.

\section{References}

Austin, A.T., Bustamante, M.M.C., Nardoto, G.B., Mitre, S.K., Perez, T., Ometto, J.P.H.B., et al., 2013. Latin America's nitrogen challenge. Science 340, 149. doi:10.1126/ science. 1231679.

Bai, Z., Li, H., Yang, X., Zhou, B., Shi, X., Wang, B., et al., 2013. The critical soil P levels for crop yield, soil fertility and environmental safety in different soil types. Plant Soil 372, 27-37. doi:10.1007/s11104-013-1696-y. 
Barbosa, A.S., 2011. Cerrado: "dor fantasma" da biodiversidade brasileira. IHU On-Line (UNISINOS. Online) 382, 11-15. <http://www.ihuonline.unisinos.br/media/pdf/ IHUOnlineEdicao382.pdf>, Portuguese, (accessed 30.10.14.).

Bennetzen, E.H., Smith, P., Soussana, J.F., Porter, J.R., 2012. Identity-based estimation of greenhouse gas emissions from crop production: case study from Denmark. Eur. J. Agron. 41, 66-72. doi:10.1016/j.eja.2012.03.010.

Bergier, I., 2013. Effects of highland land-use over lowlands of the Brazilian Pantanal. Sci. Total Environ. 463, 1060-1066. doi:10.1016/j.scitotenv.2013.06.036.

Bergier, I., Goulart, T., Monteiro, H., Franco, E., Rech, R., Silva, D., et al., 2012. Fertirrigação no contexto da agricultura de baixo carbono: resultados preliminares e diretrizes do Projeto CNPq/REPENSA em São Gabriel do Oeste. Boletim de Pesquisa. Embrapa Pantanal, Corumbá. <http://www.cpap.embrapa.br/ publicacoes/online/BP116.pdf >, in Portuguese, (accessed 30.10.14.).

Bergier, I., Soriano, E., Wiedman, G., Kososki, A., 2013a. Intensive and integrated farm systems using fermentation of swine effluent in Brazil. In: Ruane, J., Dargie, J.D., Mba, C., Boettcher, P., Makkar, H.P.S., Bartley, D.M., et al. (Eds.), Occasional Papers on Innovation in Family Farming. Biotechnologies at Work for Smallholders: Case Studies from Developing Countries in Crops, Livestock and Fish. Food and Agriculture Organization of the United Nations, pp. 109-116. <http://www.fao.org/docrep/018/i3403e/i3403e.pdf> (accessed 30.10.14.).

Bergier, I., Rech, R., Monteiro, H., Soriano, E., 2013b. User effects on chamber nitrous oxide emissions from oxisol soils in no-tillage maize fertirrigated with anaerobically digested swine manure. Environ. Nat. Resour. Res. 3 (4), doi:10.5539/enrr.v3n4p1.

Bergier, I., Fernando, M., Ramos, F.M., Bambace, L.A.W., 2014. Dam reservoirs role in carbon dynamics requires contextual landscape ecohydrology. Environ. Monit. Assess. 186, 5985-5988. doi:10.1007/s10661-014-3834-2.

Blagodatskaya, E., Kuzyakov, Y., 2008. Mechanisms of real and apparent priming effects and their dependence on soil microbial biomass and community structure: critical review. Biol. Fertil. Soils 45, 115-131. doi:10.1007/s00374-008-0334-y.

Burney, J.A., Davis, S.J., Lobell, D.B., 2010. Greenhouse gas mitigation by agricultural intensification. Proc. Natl. Acad. Sci. U.S.A. 107, 12052-12057. doi:10.1073/ pnas.0914216107.

Campbell, D.E., Lu, H., Lin, B., 2014. Emergy evaluations of the global biogeochemical cycles of six biologically active elements and two compounds. Ecol. Model. 271, 32-51. doi:10.1016/j.ecolmodel.2013.01.013.

Carvalho, J.L.N., Raucci, G.S., Frazao, L.A., Cerri, C.E.P., Bernoux, M., Cerri, C.C., 2014. Crop-pasture rotation: a strategy to reduce soil greenhouse gas emissions in the Brazilian Cerrado. Agr. Ecosyst. Environ. 183, 167-175. doi:10.1016/ j.agee.2013.11.014.

Cassidy, E.S., West, P.C., Gerber, J.S., Foley, J.A., 2013. Redefining agricultural yields: from tonnes to people nourished per hectare. Environ. Res. Lett. 8, doi:10.1088/ $1748-9326 / 8 / 3 / 034015$.

Cavalett, O., de Queiroz, J.F., Ortega, E., 2006. Emergy assessment of integrated production systems of grains, pig and fish in small farms in the South Brazil. Ecol. Model. 193, 205-224. doi:10.1016/j.ecolmodel.2005.07.023.

Chapin, F.S., III, Matson, P.A., Vitousek, P.M., 2012. Geology, soils, and sediments. In: Chapin, F.S., III, Matson, P.A., Vitousek, P.M. (Eds.), Principles of Terrestrial Ecosystem Ecology. Springer, New York, pp. 63-90. <http://link.springer.com/ chapter/10.1007/978-1-4419-9504-9_3/fulltext.html> (accessed 06.11.14.).

Clough, T.J., Condron, L.M., Kammann, C., Müller, C., 2013. A review of biochar and soil nitrogen dynamics. Agronomy 3, 275-293. doi:10.3390/agronomy3020275.

Cohen, M.J., Brown, M.T., Shepherd, K.D., 2006. Estimating the environmental costs of soil erosion at multiple scales in Kenya using emergy synthesis. Agr. Ecosyst. Environ. 114, 249-269. doi:10.1016/j.agee.2005.10.021.

Dong, X.B., Brown, M.T., Pfahler, D., Ingwersen, W.W., Kang, M.Y., Jin, Y., et al., 2012. Carbon modeling and emergy evaluation of grassland management schemes in Inner Mongolia. Agr. Ecosyst. Environ. 158, 49-57. doi:10.1016/j.agee.2012.04.027.

Eggleston, H.S., Buendia, L., Miwa, K., Ngara, T., Tanabe, K. (Eds.), 2006. 2006 IPCC Guidelines for National Greenhouse Gas Inventories, Prepared by the National Greenhouse Gas Inventories Programme, vol. 4. IGES, Japan. <http://www.ipccnggip.iges.or.jp/public/2006gl/vol4.html> (accessed 24.10.14.).

EOSWEB, 2014. Surface meteorology and solar energy: a renewable energy resource web site. <https://eosweb.larc.nasa.gov/sse/> (accessed 24.10.14.).

FAO, 2013. The State of Food and Agriculture: Food Systems for Better Nutrition. Food and Agriculture Organization of the United Nations, Rome. <http://www.fao.org/ docrep/018/i3300e/i3300e00.htm> (accessed 24.10.14.).

Galdino, S., 2012. Estimativa da Perda de Terra Sob Pastagens Cultivadas em Solos Arenosos da Bacia Hidrográfica Do Alto Taquari - MS/MT (Ph.D. thesis). State University of Campinas (in Portuguese).

Gatiboni, L.C., Smyth, T.J., Schmitt, D.E., Cassol, P.C., de Oliveira, C.M.B., 2014. Proposta de Limites Críticos Ambientais de Fósforo para Solos de Santa Catarina. UDESC/ CAV, Lages. <http://www.cav.udesc.br/arquivos/id_submenu/339/boletim_tecnico _cav_gatiboni_et_al_2014.pdf >, in Portuguese, (accessed 06.11.14.).

GeoNode. 2014. <http://geoinfo.cnpm.embrapa.br/maps/724/view> (accessed 24.10.14.).

Giannetti, B.F., Ogura, Y., Bonilla, S.H., Almeida, C.M.V.B., 2011. Emergy assessment of a coffee farm in Brazilian Cerrado considering in a broad form the environmental services, negative externalities and fair price. Agr. Syst. 104, 679-688. doi:10.1016/j.agsy.2011.08.001.

Godfray, H.C.J., Beddington, J.R., Crute, I.R., Haddad, L., Lawrence, D., Muir, J.F., et al., 2010. Food security: the challenge of feeding 9 billion people. Science 327, 812-818. doi:10.1126/science.1185383.

IBGE, 2012. Instituto Brasileiro de Geografía e Estatística, Produção da pecuária municipal. <http://biblioteca.ibge.gov.br/visualizacao/periodicos/84/ppm_2012 _v40_br.pdf>, in Portuguese, (accessed 24.10.14.).
Kahlon, M.S., Lal, R., Ann-Varughese, M., 2013. Twenty two years of tillage and mulching impacts on soil physical characteristics and carbon sequestration in Central Ohio. Soil Till. Res. 126, 151-158. doi:10.1016/j.still.2012 .08 .001 .

Kunrath, T.R., Cadenazzi, M., Brambilla, D.M., Anghinoni, I., Moraes, A., Barro, R.S., et al., 2014. Management targets for continuously stocked mixed oat $\times$ annual ryegrass pasture in a no-till integrated crop-livestock system. Eur. J. Agron. 57, 71-76. doi:10.1016/j.eja.2013.09.013.

Kunz, A., Miele, M., Steinmetz, R.L.R., 2009. Advanced swine manure treatment and utilization in Brazil. Bioresource Technol. 100, 5485-5489. doi:10.1016/ j.biortech.2008.10.039.

Lal, R., 2004. Soil carbon sequestration impacts on global climate change and food security. Science 304, 1623-1627. doi:10.1126/science.1097396.

Lal, R., 2013. Food security in a changing climate. Ecohydrol. Hydrobiol. 13, 8-21. doi:10.1016/j.ecohyd.2013.03.006

Lapola, D.M., Martinelli, L.A., Peres, C.A., Ometto, J.P.H.B., Ferreira, M.E., Nobre, C.A. et al., 2014. Pervasive transition of the Brazilian land-use system. Nat. Clim. Change 4, 27-35. doi:10.1038/nclimate2056.

Lemaire, G., Franzluebbers, A., Carvalho, P.C.F., Dedieu, B., 2014. Integrated croplivestock systems: strategies to achieve synergy between agricultural production and environmental quality. Agr. Ecosyst. Environ. 190, 4-8. <http://dx.doi.org/ 10.1016/j.agee.2013.08.009>.

Lu, H.F., Lin, B.L., Campbell, D.E., Sagisaka, M., Ren, H., 2012. Biofuel vs. biodiversity? Integrated emergy and economic cost-benefit evaluation of rice-ethanol production in Japan. Energy 46, 442-450. doi:10.1016/j.energy.2012.08.005.

MAPA, 2012. Brasil. Ministério da Agricultura, Pecuária e Abastecimento, Plano setorial de mitigação e de adaptação às mudanças climáticas para a consolidação de uma economia de baixa emissão de carbono na agricultura : plano ABC (Agricultura de Baixa Emissão de Carbono)/Ministério da Agricultura, Pecuária e Abastecimento, Ministério do Desenvolvimento Agrário, coordenação da Casa Civil da Presidência da República. MAPA/ACS, Brasília. <http://www .agricultura.gov.br/arq_editor/download.pdf>, in Portuguese, (accessed 06.11.14.)

Moraes, A., Carvalho, P.C.F., Anghinoni, I., Lustosa, S.B.C., Costa, S.E.V.G.A., Kunrath, T.R., 2014. Integrated crop-livestock systems in the Brazilian subtropics. Eur. J. Agron. 57, 4-9. doi:10.1016/j.eja.2013.10.004.

Mueller, N.D., Gerber, J.S., Johnston, M., Ray, D.K., Ramankutty, N., Foley, J.A., 2012. Closing yield gaps through nutrient and water management. Nature 490, 254-257. doi:10.1038/nature11420.

Odum, H.T., 1988. Self organization, transformity and information. Science 242, 1132-1139. <http://www.jstor.org/stable/1702630> (accessed 06.11.14.).

Odum, H.T., 1996. Environmental Accounting: Emergy and Environmental Decision Making. John Wiley, New York.

Odum, H.T., Brown, M.T., Brandt-Williams, S.L., 2000. Handbook of Emergy Evaluation, Folio 1: Introduction and Global Budget. Center for Environmental Policy, Environmental Engineering Sciences. University of Florida, Gainesville. <http:// www.cep.ees.ufl.edu/emergy/documents/folios/Folio_01.pdf $>$ (accessed 24.10.14.)

Ortega, E., Cavalett, O., Bonifácio, R., Watanabe, M., 2005. Brazilian soybean production: emergy analysis with an expanded scope. Bulletin of Science, Technology \& Society 25 (4), 323-334. <http://organicagcenter.ca/DOCs ResearchPapers/Ortega_etal_2005.pdf $>$ (accessed 24.10.14.).

Pittelkow, C.M., Liang, X., Linquist, B.A., van Groenigen, K.J., Lee, J., Lundy, M.E., et al., 2014. Productivity limits and potentials of the principles of conservation agriculture. Nature, doi:10.1038/nature13809.

Piva, J.T., Dieckow, J., Bayer, C., Zanatta, J.A., de Moraes, A., Pauletti, V., et al., 2012. No-till reduces global warming potential in a subtropical Ferralsol. Plant Soil 361, 359-373. doi:10.1007/s11104-012-1244-1.

Rada, N., 2013. Assessing Brazil's Cerrado agricultural miracle. Food Policy 38, 146-155. doi:10.1016/j.foodpol.2012.11.002.

Ramirez, G.H., 2007. Soil carbon sequestration and greenhouse gas fluxes in the eastern corn belt, (Ph.D. thesis). Purdue University. < http://search.proquest.com/ docview/304824728? accountid=8113 $>$ (accessed 06.11.14.).

Ren, T., Wang, J., Chen, Q., Zhang, F., Lu, S., 2014. The effects of manure and nitrogen fertilizer applications on soil organic carbon and nitrogen in a high-input cropping system. PLoS ONE 9 (5), e97732. doi:10.1371/journal.pone.0097732.

Rieger, L.O., 2006. Motor estacionário modificado para gás metano. Patent number: BRMU8602925U, F02B75/02, 06 November 2006, 01 July 2008. Applicants: Retificadora Centro Sul Ltda.; Rieger Irrigação Ltda. <http://www.inpi.gov.br/ portal/artigo/busca_patentes> (accessed 24.10.14.).

Rótolo, G.C., Rydberg, T., Lieblein, G., Francis, C., 2007. Emergy evaluation of grazing cattle in Argentina's Pampas. Agr. Ecosyst. Environ. 119, 383-395. <http://dx.doi.org/10.1016/j.agee.2006.08.011>.

Rockstrom, J., Steffen, W., Noone, K., Persson, A., Chapin, F.S., Lambin, E.F., et al., 2009. A safe operating space for humanity. Nature 461, 472-475. doi:10.1038/461472a.

Rugani, B., Pulselli, F.M., Niccolucci, V., 2011. Emergy assessment of cinta senese breeding and comparison with conventional pig production. In: Brown, M.T. Sweeney, S., Campbell, D.E., Huang, S., Ortega, E., Rydberg, T., et al. (Eds.), Emergy Synthesis 6: Theory and Applications of the Emergy Methodology. Center for Environmental Policy, University of Florida, Gainesville, pp. 347-358. <http:// www.cep.ees.ufl.edu/emergy/documents/conferences/ERC06_2010/ ERC06_2010_Chapter_31.pdf > (accessed 06.11.14.).

Silva, F.D., Amado, T.J.C., Bredemeier, C., Bremm, C., Anghinoni, I., Carvalho, P.C.F., 2014 Pasture grazing intensity and presence or absence of cattle dung input and its relationships to soybean nutrition and yield in integrated crop-livestock systems under no-till. Eur. J. Agron. 57, 84-91. doi:10.1016/j.eja.2013.10.009.

Silva, J.S.V., Abdon, M.M., Silva, S.M.A., Moraes, J.A., 2011. Evolution of deforestation in the Brazilian Pantanal and surroundings in the timeframe 1976-2008. 
Geografia 36, 35-55. <http://www.periodicos.rc.biblioteca.unesp.br/index.php/ ageteo/article/view/5137> (accessed 24.10.14.)

Strassburg, B.B.N., Latawiec, A.E., Barioni, L.G., Nobre, C.A., da Silva, V.P., Valentim, J.F., et al., 2014. When enough should be enough: improving the use of current agricultural lands could meet production demands and spare natural habitats in Brazil. Global Environ. Change 28, 84-97. doi:10.1016/ j.gloenvcha.2014.06.001.

Strauch, M., Lima, J.E.F.W., Volk, M., Lorz, C., Makeschin, F., 2013. The impact of Best Management Practices on simulated streamflow and sediment load in a Central Brazilian catchment. J. Environ. Manage. 127, S24-S36. doi:10.1016/ j.jenvman.2013.01.014.

Teixeira, M.B., 2012. Análise do impacto ambiental de unidades agropecuárias. Estudo de caso: microbacia do rio Pinhal, Santa Catarina (M.Sc. dissertation). State University of Campinas. <http://www.unicamp.br/fea/ortega/ extensao/dissertacao_MarianaBarrosTeixeira.pdf $>$, in Portuguese, (accessed 06.11.14.).

Tubiello, F.N., Salvatore, M., Cóndor Golec, R.D., Ferrara, A., Rossi, S., Biancalani, R. et al., 2014. Agriculture, forestry and other land use emissions by sources and removals by sinks: 1990-2011 analysis. FAO Statistics Division. Working Paper Series ESS/14-02. <http://www.fao.org/docrep/019/i3671e/i3671e.pdf> (accessed 24.10.14.).

Ulgiati, S., Brown, M.T., 2001. Emergy accounting of human-dominated, large-scale ecosystems. In: Jørgensen, S.E. (Ed.), Thermodynamics and Ecological Modelling. CRC Press LLC, Lewis Publishers, Boca Raton, FL, pp. 63-113.

USGS, 2014. Earth explorer. <http://earthexplorer.usgs.gov/> (accessed 24.10.14.).
Valin, H., Havlik, P., Mosnier, A., Herrero, M., Schmid, E., Obersteiner, M., 2013. Agricultural productivity and greenhouse gas emissions: trade-offs or synergies between mitigation and food security? Environ. Res. Lett. 8, doi:10.1088/17489326/8/3/035019.

Wang, X., Chen, Y., Sui, P., Gao, W., Qin, F., Zhang, J., et al., 2014. Emergy analysis of grain production systems on large-scale farms in the North China Plain based on LCA. Agr. Syst. 128, 66-78. doi:10.1016/j.agsy.2014.03.005.

Wantzen, K.M., Couto, E.G., Mund, E.E., Amorim, R.S.S., Siqueira, A., Tielborger, K. et al., 2012. Soil carbon stocks in stream-valley-ecosystems in the Brazilian Cerrado agroscape. Agr. Ecosyst. Environ. 151, 70-79. doi:10.1016/j.agee .2012.01.030.

Watanabe, M.D.B., Ortega, E., 2014. Dynamic emergy accounting of water and carbon ecosystem services: a model to simulate the impacts of land-use change. Ecol. Model. 271, 113-131. doi:10.1016/j.ecolmodel.2013.03.006.

Wood, A., Stedman-Edwards, P., Mang, J. (Eds.), 2000. The Root Causes of Biodiversity Loss. World Wildlife Fund (WWF) and Earthscan Publications, London, UK.

World Bank, 2010. Brazil Low Carbon Country Case Study. @ World Bank, Washington, DC. <https://openknowledge.worldbank.org/handle/10986/17526> (accessed 24.10.14.).

Zaehle, S., Ciais, P., Friend, A.D., Prieur, V., 2011. Carbon benefits of anthropogenic reactive nitrogen offset by nitrous oxide emissions. Nat. Geosci. 4, 601-605. doi:10.1038/NGEO1207.

Zalewski, M., 2002. Ecohydrology: the use of ecological and hydrological processes for sustainable management of water resources/Ecohydrologie: la prise en compte de processus éécologiques et hydrologiques pour la gestion durable des ressources en eau. Hydrol. Sci. J. 47 (5), 823-832. doi:10.1080/02626660209492986. 